\title{
Impact of transport model errors on the global and regional methane emissions estimated by inverse modelling
}

\author{
R. Locatelli ${ }^{1}$, P. Bousquet ${ }^{1}$, F. Chevallier ${ }^{1}$, A. Fortems-Cheney ${ }^{1}$, S. Szopa ${ }^{1}$, M. Saunois ${ }^{1}$, A. Agusti-Panareda ${ }^{2}$, \\ D. Bergmann ${ }^{3}$, H. Bian ${ }^{4}$, P. Cameron-Smith ${ }^{3}$, M. P. Chipperfield ${ }^{5}$, E. Gloor ${ }^{5}$, S. Houweling ${ }^{6,7}$, S. R. Kawa ${ }^{4}$, \\ M. Krol ${ }^{6,7,8}$, P. K. Patra ${ }^{9}$, R. G. Prinn ${ }^{10}$, M. Rigby ${ }^{11,10}$, R. Saito ${ }^{9}$, and C. Wilson ${ }^{5}$ \\ ${ }^{1}$ Laboratoire des Sciences du Climat et de l'Environnement, LSCE - UMR8212, Gif sur Yvette, France \\ ${ }^{2}$ European Centre for Medium-Range Weather Forecasts, Shinfield Park, Reading, Berkshire, RG2 9AX, UK \\ ${ }^{3}$ Atmospheric, Earth, and Energy Division, Lawrence Livermore National Laboratory, 7000 East Avenue, \\ Livermore, CA 94550, USA \\ ${ }^{4}$ Goddard Earth Sciences and Technology Center, NASA Goddard Space Flight Center, Code 613.3, \\ Greenbelt, MD 20771, USA \\ ${ }^{5}$ Institute for Climate and Atmospheric Science, School of Earth and Environment, University of Leeds, Leeds, LS2 9JT, UK \\ ${ }^{6}$ SRON Netherlands Institute for Space Research, Sorbonnelaan 2, 3584 CA Utrecht, the Netherlands \\ ${ }^{7}$ Institute for Marine and Atmospheric Research Utrecht (IMAU), Princetonplein 5, 3584 CC Utrecht, the Netherlands \\ ${ }^{8}$ Wageningen University and Research Centre, Droevendaalsesteeg 4, 6708 PB Wageningen, the Netherlands \\ ${ }^{9}$ Research Institute for Global Change/JAMSTEC, 3173-25 Show-machi, Yokohama, 2360001, Japan \\ ${ }^{10}$ Center for Global Change Science, Building 54, Massachusetts Institute of Technology, Cambridge, MA 02139, USA \\ ${ }^{11}$ School of Chemistry, University of Bristol, Bristol, BS8 1TS, UK \\ Correspondence to: R. Locatelli (robin.locatelli@1sce.ipsl.fr)
}

Received: 25 March 2013 - Published in Atmos. Chem. Phys. Discuss.: 24 April 2013

Revised: 19 August 2013 - Accepted: 22 August 2013 - Published: 8 October 2013

\begin{abstract}
A modelling experiment has been conceived to assess the impact of transport model errors on methane emissions estimated in an atmospheric inversion system. Synthetic methane observations, obtained from 10 different model outputs from the international TransCom- $\mathrm{CH}_{4}$ model inter-comparison exercise, are combined with a prior scenario of methane emissions and sinks, and integrated into the three-component PYVAR-LMDZ-SACS (PYthon VARiational-Laboratoire de Météorologie Dynamique model with Zooming capability-Simplified Atmospheric Chemistry System) inversion system to produce 10 different methane emission estimates at the global scale for the year 2005. The same methane sinks, emissions and initial conditions have been applied to produce the 10 synthetic observation datasets. The same inversion set-up (statistical errors, prior emissions, inverse procedure) is then applied to derive flux estimates by inverse modelling. Consequently, only differences in the modelling of atmospheric transport may cause differences in the estimated fluxes.
\end{abstract}

In our framework, we show that transport model errors lead to a discrepancy of $27 \mathrm{Tg} \mathrm{yr}^{-1}$ at the global scale, representing $5 \%$ of total methane emissions. At continental and annual scales, transport model errors are proportionally larger than at the global scale, with errors ranging from $36 \mathrm{Tg} \mathrm{yr}^{-1}$ in North America to $7 \mathrm{Tg} \mathrm{yr}^{-1}$ in Boreal Eurasia (from 23 to $48 \%$, respectively). At the model grid-scale, the spread of inverse estimates can reach $150 \%$ of the prior flux. Therefore, transport model errors contribute significantly to overall uncertainties in emission estimates by inverse modelling, especially when small spatial scales are examined. Sensitivity tests have been carried out to estimate the impact of the measurement network and the advantage of higher horizontal resolution in transport models. The large differences found between methane flux estimates inferred in these different configurations highly question the consistency of transport model errors in current inverse systems.

Future inversions should include more accurately prescribed observation covariances matrices in order to limit 
the impact of transport model errors on estimated methane fluxes.

\section{Introduction}

Methane $\left(\mathrm{CH}_{4}\right)$ is the second most important anthropogenically emitted long-lived greenhouse gas in the atmosphere. While $\mathrm{CH}_{4}$ mixing ratios have varied between 350 and 800 parts per billion by volume (ppb) over the past $650000 \mathrm{yr}$ (Spahni et al., 2005), current atmospheric methane levels have increased by more than $600 \mathrm{ppb}$ since 1950 (Etheridge et al., 1992), reaching a global mean of $1794 \mathrm{ppb}$ in 2009 (Dlugokencky et al., 2011). Methane is primarily emitted by biogenic sources linked to anaerobic decomposition of organic matter by methanogenic bacteria (in wetlands, rice paddies, animal digestion, waste, landfills and by termites). Emissions also involve thermogenic (geological sources, fossil fuel extraction, transportation and use) and pyrogenic (biomass and biofuel burning) sources. Global emission estimates range from 500 to $600 \mathrm{Tg} \mathrm{yr}^{-1}$ (Denman et al., 2007). Typical ranges for estimates of global emissions for each process are of $\pm 30 \%$ (e.g. agriculture and waste) to more than $\pm 100 \%$ (fresh water emissions) (Kirschke et al., 2013). Atmospheric methane is removed mainly by the oxidation by $\mathrm{OH}$ radicals in the troposphere ( $90 \%$ of the total sink). Additional sinks are the destruction in dry soils (methanotrophic bacteria), the oxidation in the stratosphere $\left(\mathrm{OH}, \mathrm{O}\left({ }^{1} \mathrm{D}\right)\right)$ and the oxidation by active chlorine in the marine planetary boundary layer (PBL) (Allan et al., 2007). Because methane both plays a key role in air quality issues (Fiore et al., 2002) and is 23 times more effective as a greenhouse gas than $\mathrm{CO}_{2}$ on a 100-yr horizon (Denman et al., 2007), it is pertinent to better understand and to accurately quantify the spatial and temporal patterns of methane sources and sinks. Disagreements between recent studies (Kai et al., 2011; Levin et al., 2012; Aydin et al., 2011; Simpson et al., 2012; Rigby et al., 2008; Montzka et al., 2011; Bousquet et al., 2006, 2011) explaining the weakening in the $\mathrm{CH}_{4}$ growth rate from 2000 to 2006 and its increase since 2007 reinforce the idea that methane fluxes are poorly understood, both for their longterm mean and for their inter-annual variations.

Since the end of the nineties, several research groups have developed inverse methods to estimate $\mathrm{CH}_{4}$ fluxes from global to regional scales by optimally combining $\mathrm{CH}_{4}$ measurements with prior information and atmospheric chemical transport models (CTMs). Based on the Bayesian paradigm, a cost function is minimized either by analytical (Hein et al., 1997; Houweling et al., 1999; Bousquet et al., 2006; Chen and Prinn, 2006) or variational techniques (Pison et al., 2009; Meirink et al., 2008). The former solves for fluxes from large regions at typical monthly time resolution using lowfrequency surface observations as constraints. The latter uses a minimization technique that can be used for a larger inverse problem, assimilating high-frequency surface measure- ments and satellite data, and solving for fluxes at the model resolution, therefore avoiding most of the aggregation errors of "large-region" inversions (Kaminski et al., 2001). Although these two methods differ in their implementation, they are both based on CTMs to link emissions and sinks to atmospheric $\mathrm{CH}_{4}$ concentrations. Each CTM has its own characteristics: horizontal and vertical resolutions, boundary and initial conditions, meteorological drivers, advection schemes, sub-grid parameterization schemes for convection, turbulence or clouds, etc. Therefore, it is important to assess the sensitivity of estimated fluxes to the CTM used in the inversion process.

Since 1993, the TransCom experiment has compared the ability of transport models to represent trace gas concentrations in the atmosphere. Chronologically, the TransCom community characterized the atmospheric transport of $\mathrm{CO}_{2}$ (Law et al., 1996; Geels et al., 2007), $\mathrm{SF}_{6}$ (Denning et al., 1999), ${ }^{222} \mathrm{Rn}$ (Taguchi et al., 2011), and, more recently, $\mathrm{CH}_{4}$ (Patra et al., 2011). One major outcome of the TransCom experiment, described in Patra et al. (2011), was that deficiencies in the ability of CTMs to accurately reproduce atmospheric methane concentrations hindering efforts to improve our knowledge on sources and sinks of methane. These limitations were thought to be due to both errors in the meteorological datasets used as drivers of the CTMs and in the CTM parameterizations. For the following, we define "forcing errors" as errors in the meteorological fields used by the CTMs and "model errors" as errors in the CTMs themselves. Hereafter, "transport model errors" will be used to group together forcing and model errors.

For a long time, efforts to deduce regional fluxes of $\mathrm{CH}_{4}$ have been limited by the low density, in both space and time, of atmospheric observations (Gurney et al., 2002). However, with the increasing spatial and temporal density of surface observing networks and the availability of satellite data, this limitation is becoming less dominant, putting more pressure on forcing and model errors. Furthermore, as scientific objectives are moving towards regional to local flux estimates, more observations are being developed closer to emissions sources. This implies that CTMs need to improve their ability to represent processes that are important at these scales, or at least to ensure that the forcing and model errors are properly quantified and accounted for in atmospheric inversions. In this context, the main goal of our study is to quantify the impact of the misrepresentation of atmospheric processes by CTMs on the methane fluxes estimated by inverse modelling.

At present, forcing and model errors are either approximated or neglected in inversions, although studies aiming at quantifying these errors have shown a potentially high impact on the inverse estimates. In particular, Gerbig et al. (2008) focused on vertical mixing uncertainties for $\mathrm{CO}_{2}$ inversions and highlighted large values of errors related to atmospheric transport. Stephens et al. (2007) showed the large impact of deficiencies in the modelling of $\mathrm{CO}_{2}$ vertical transport for emission estimations by inverse modelling. Lin and Gerbig 
(2005) have assessed that horizontal wind was accountable for a $5 \mathrm{ppm}$ error in the modelling of $\mathrm{CO}_{2}$ during summertime. Engelen et al. (2002) showed that failure to properly account for these errors acts as a hard constraint on the inversion and produces incorrect solutions to the problem. Gloor et al. (1999) even claimed that inversions were not reliable for $\mathrm{CO}_{2}$ flux monitoring because of the magnitude of transport model errors. The impact of transport model errors on inversions has already been studied for $\mathrm{CO}_{2}$ (Gurney et al., 2002; Baker et al., 2006), but, to our knowledge, no study has investigated this issue for $\mathrm{CH}_{4}$ yet.

In this paper, we estimate the impact of transport model errors on inverted $\mathrm{CH}_{4}$ fluxes using one variational inversion scheme, one flux scenario, and 10 different synthetic observation datasets built from the model database of the TransCom- $\mathrm{CH}_{4}$ experiment (Patra et al., 2011). Section 2 describes the methodology and the synthetic data used for our inversions. Section 3.1 presents the main differences in the forward modelling of $\mathrm{CH}_{4}$ concentrations due to the different CTMs used in Patra et al. (2011). Such differences are useful to better understand the inversion results, which are explored in Sect. 3.2. Sensitivity tests of the impact of CTM resolution (Sect. 3.3) and density of the measurement network (Sect. 3.4) on the inverse estimates are then analysed. Section 4 discusses the limitations of this synthetic experiment and the implication of our work to better represent transport model errors in future inversions.

\section{Methodology}

\subsection{The synthetic experiment}

This study follows the TransCom- $\mathrm{CH}_{4}$ intercomparison experiment (Patra et al., 2011), which aimed to quantify the role of transport, flux distribution and chemical loss in simulating the seasonal cycle, synoptic variations and the diurnal cycle of $\mathrm{CH}_{4}$ mixing ratio. Significant differences in CTM simulations of $\mathrm{CH}_{4}$ were identified in this work. For example, large differences were found in the $\mathrm{CH}_{4}$ mixing ratios simulated by the different CTMs in the transition region between the troposphere and the stratosphere, especially at heights where the maximum vertical gradient in $\mathrm{CH}_{4}$ occurred. A common protocol was followed in which each model used the same emissions, sinks and initial conditions. Therefore, simulated $\mathrm{CH}_{4}$ mixing ratios for the different models should differ only because of the modelling of atmospheric transport by the CTMs (model errors) and the meteorology used to force them (forcing errors). In the TransCom experiment it was not possible to separate these two effects as simulations testing different meteorological forcings on the same CTM were not provided. The database of the TransCom- $\mathrm{CH}_{4} \mathrm{ex}-$ periment includes outputs of hourly $\mathrm{CH}_{4}$ mixing ratios at 166 surface stations, 6 tall towers and 12 vertical profiles, each for 6 different emission scenarios.
Here we apply a 2-step methodology (Fig. 1) to quantify the impact of the different models on the inverted methane fluxes. In a first step, daily-mean $\mathrm{CH}_{4}$ concentrations are extracted from the ten forward simulations of the TransCom$\mathrm{CH}_{4}$ database, using their IAV INV (inversion-derived emissions, herein called INV) scenario, which includes monthlyand inter-annually varying emissions provided by Bousquet et al. (2006). In doing so, we create 10 synthetic daily-mean observation datasets at selected sites. In a second step, the same emission scenario (INV) is combined with each synthetic observation dataset to infer optimized fluxes using the PYVAR (PYthon VARiational) variational inversion system, developed at LSCE (Laboratoire des Sciences du Climat et de l'Environnement) (Chevallier et al., 2005) and based on LMDZ-SACS CTM (one of the TransCom models). As the INV scenario is also used to generate synthetic observation, it can be considered as the "true" flux, hereafter referred as the "target". Therefore, fluxes derived using the LMDZ-SACS (Laboratoire de Météorologie Dynamique model with Zooming capability-Simplified Atmospheric Chemistry System) synthetic observations in the inversion system give exactly the target fluxes, within the numerical errors. $\mathrm{CH}_{4}$ fluxes are estimated in all the grid cells of LMDZ-SACS for eight-day periods using the PYVAR inversion algorithm (see Sect. 2.3). By repeating the inversion process for each synthetic observation dataset, ten estimates of $\mathrm{CH}_{4}$ fluxes are obtained. Assuming that the range of the ten CTMs used here cover the typical range of transport model errors (see Sect. 2.2), the comparison between these estimates provides an estimate of the influence of transport model errors on the $\mathrm{CH}_{4}$ fluxes. Indeed, the differences found in the inverted $\mathrm{CH}_{4}$ fluxes are only due to discrepancies in the modelling of atmospheric transport by the different CTMs and in the meteorological analyses/reanalyses fields driving them.

\subsection{The chemistry transport models}

Results from ten CTMs have been extracted from the TransCom- $\mathrm{CH}_{4}$ experiment: ACTM (Atmospheric Chemistry Transport Model) (Patra et al., 2009), IFS (Integrated Forecast System) (http://www.ecmwf.int/research/ifsdocs/ CY37r2), IMPACT (Integrated Massively Parallel Atmospheric Chemical Transport) (Rotman, 2004), IMPACT-High resolution (Rotman, 2004), LMDZ-SACS (version 4) (Hourdin et al., 2006; Pison et al., 2009), MOZART (version 4) (Model for Ozone and Related Chemical Tracers) (Emmons et al., 2010)), PCTM (Parallel Climate Transition Model) (Kawa et al., 2004; Bian et al., 2006), TM5 (Transport Model, version 5) (Krol et al., 2005), TM5-High resolution (Krol et al., 2005) and TOMCAT (Toulouse Off-line Model of Chemistry and Transport) (Chipperfield, 2006) (see Table 1 for more details).

These CTMs represent the diversity existing in the research community with horizontal resolutions ranging from $6^{\circ} \times 4^{\circ}$ (TM5) to $0.7^{\circ} \times 0.7^{\circ}$ (IFS) and vertical discretisation 
Table 1. Main characteristics (vertical resolution, horizontal resolution and meteorological drivers) of the TransCom models used in this experiment.

\begin{tabular}{lcll}
\hline $\begin{array}{l}\text { Model } \\
\text { name }\end{array}$ & $\begin{array}{c}\text { Vertical } \\
\text { resolution }\end{array}$ & $\begin{array}{l}\text { Horizontal } \\
\text { resolution }\end{array}$ & Meteorological fields \\
\hline ACTM & $67 \sigma$ & $2.8 \times 2.8^{\circ}$ & NCEP2 \\
IFS & $60 \eta$ & $0.7 \times 0.7^{\circ}$ & ERA-interim \\
IMPACT & $55 \eta$ & $5.0 \times 4.0^{\circ}$ & NASA/GSFC/GEOS 4 \\
IMPACT $1 \times 1.25$ & $55 \eta$ & $1.25 \times 1.0^{\circ}$ & NASA/GSFC/GEOS 4 \\
LMDZ-SACS & $19 \eta$ & $3.75 \times 2.5^{\circ}$ & ECMWF \\
MOZART & $28 \sigma$ & $1.8 \times 1.8^{\circ}$ & NCEP/NCAR \\
PCTM & $58 \eta$ & $1.25 \times 1.0^{\circ}$ & NASA/GSFC/GEOS 5 \\
TM5 & $25 \eta$ & $6.0 \times 4.0^{\circ}$ & ECMWF, ERA-interim \\
TM5 $1 \times 1$ & $25 \eta$ & $1.0 \times 1.0^{\circ}$ & ECMWF, ERA-interim \\
TOMCAT & $60 \eta$ & $2.8 \times 2.8^{\circ}$ & ECMWF, ERA-40/interim \\
\hline
\end{tabular}

${ }^{1} \sigma$ vertical coordinates are pressure divided by surface pressure, $\eta$ vertical coordinates are a hybrid sigma-pressure coordinate.

ranging from 19 (LMDZ-SACS) to 67 layers (ACTM) with various coordinate systems (sigma vertical and hybrid-sigma pressure). Focusing on the representation of atmospheric transport, two groups of models can be distinguished: models using the meteorological fields from weather forecast analyses directly (IFS, IMPACT, MOZART, PCTM, TM5 and TOMCAT) and models nudging towards horizontal winds and/or temperature (ACTM and LMDZ-SACS). The different CTMs also use a large diversity of meteorological drivers: different versions of NCEP/NCAR (National Centers for Environmental Prediction/National Center for Atmospheric Research), NASA/GSFC/GEOS (National Aeronautics Space Administration/Goddard Space Flight Center/Goddard Earth Observation System) (version 4 and 5), ECMWF (European Centre for Medium-Range Weather Forecasts/ECMWF Reanalysis) (ERA-40 and ERA-interim) and JCDAS (Japan Meteorological Agency (JMA) Climate Data Assimilation System).

Although the parameterization schemes implemented in the CTMs may have been slightly modified or adapted from the original scheme, the main schemes of the different CTMs are referenced in Table 2. The different schemes, implemented in the models of this experiment, describing advection are Lin and Rood (1996), Leer (1977), Hourdin and Armengaud (1999), Hortal (2002), Russell and Lerner (1981) and Prather (1986). Several CTMs use Holtslag and Boville (1993) or an adaptation of this scheme to parameterize the planetary boundary layer mixing, although Walton et al. (1988), Laval et al. (1981), Louis (1979), Holtslag and Moeng (1991), Köhler et al. (2011) and Lock et al. (2000) are also used. The parameterization of convection processes is implemented in the CTMs by using different adaptations of the Tiedtke (1989), Zhang and McFarlane (1995), Bechtold et al. (2008), Rasch and Kristjánsson (1998) and Arakawa and Schubert (1974) schemes.

The CTMs used in this experiment are distinguished both by the reanalysis/analysis fields used to drive the CTMs and by their own characteristics (for example, resolution and parameterization schemes). As a result, this experiment studies the impact on methane fluxes of these two contributions together (errors in meteorological drivers and errors in the models themselves) with no real possibility to separate them.

Five additional model output datasets (ACCESS/Australian Community Climate and Earth System Simulator, Corbin and Law, 2011; CAM/Community Atmosphere Model, Gent et al., 2010; CCAM/CSIRO Conformal-Cubic Atmospheric Model, Law et al., 2006; GEOS-Chem 3-D chemistry transport model, Fraser et al., 2011; Pickett-Heaps et al., 2011 and NIES/National Institute for Environmental Studies 3-D chemical transport model, Belikov et al., 2011, 2013) are available in the TransCom database. Unfortunately, some specific characteristics of these simulations make them unsuitable for our study. Indeed, we have chosen only to focus on the model and forcing errors and neglect all other sources of error on the estimated fluxes. For example, the different $O H$ distribution used in GEOS-Chem simulation influences the chemical sink and may lead to misinterpretation of the impact of transport model errors on the estimated fluxes. One can expect the same issue with CAM, CCAM and NIES since the total atmospheric burden of methane in these three models differs significantly from the atmospheric burden of LMDZ-SACS. The differences in mole fraction between LMDZ-SACS and the discarded models range typically from $20 \mathrm{ppb}$ up to $42 \mathrm{ppb}$. Only models with differences of less than $5 \mathrm{ppb}$ from LMDZ-SACS were retained, such discrepancies being thought to be primarily due to transport differences impacting the location and magnitude of the $\mathrm{OH}$ sink relative to $\mathrm{CH}_{4}$. The ACCESS model, whose meteorology was not nudged towards real observations, has also been removed, since it cannot be expected to realistically simulate synoptic variations, which are essential in an inverse system using daily data.

\subsection{Set-up of the PYVAR-LMDZ-SACS inversion system}

The PYVAR-LMDZ-SACS system (Chevallier et al., 2005; Pison et al., 2009) finds the optimal state of $\mathrm{CH}_{4}$ fluxes given $\mathrm{CH}_{4}$ observations and a background estimate of fluxes using Bayesian inference formulated into a variational framework. The system iteratively minimizes the cost function $J$ (Eq. 1) using an adjoint approach (Errico, 1997) and provides the best linear unbiased estimate, $\boldsymbol{x}$. The methane fluxes contained in $\boldsymbol{x}$ are optimized for eight-day periods in all the grid cells of the model. The cost function $J$ is a measure of both the discrepancies between measurements and simulated mixing ratios and between the background fluxes and the estimated fluxes, weighted by their respective uncertainties, expressed in the covariance matrices $\mathbf{R}$ (measurement) and $\mathbf{B}$ (prior fluxes). The mathematical theory concepts are 
not detailed here, but may be found in Tarantola (2005).

$J(x)=(\mathbf{y}-\mathbf{H} \boldsymbol{x})^{T} \mathbf{R}^{-1}(\boldsymbol{y}-\mathbf{H} \boldsymbol{x})+\left(\boldsymbol{x}-\boldsymbol{x}^{b}\right)^{T} \mathbf{B}^{-1}\left(\boldsymbol{x}-\boldsymbol{x}^{b}\right)(1)$

$\mathbf{B}$ is the prior error covariance matrix with respect to the INV emission scenario. Its diagonal is filled in with the variances set to $100 \%$ of the square of the maximum of emissions over the eight neighbouring cells during each month. Off diagonal terms of $\mathbf{B}$ (covariances) are based on correlation e-folding lengths $(500 \mathrm{~km}$ over land and $1000 \mathrm{~km}$ over sea). No temporal correlations are considered here. $x^{b}$ is the prior estimate using fluxes from the INV scenario.

$\mathbf{H}$, the observation operator connecting the measurement space to the flux space, is represented here by the off-line version of the general circulation model of the Laboratoire de Météorologie Dynamique (LMDZ) (Hourdin et al., 2006), complemented by a simplified chemistry module (SACS) to represent the oxidation chain of methane (Pison et al., 2009). Here, OH fields (Spivakovsky et al., 2000) and loss rates, due to reactions of $\mathrm{CH}_{4}$ with $\mathrm{Cl}$ and $\mathrm{O}\left({ }^{1} \mathrm{D}\right)$, are prescribed as in Patra et al. (2011). LMDZ-SACS is run with a horizontal resolution of $2.5^{\circ} \times 3.75^{\circ}$ and with 19 vertical levels.

$\boldsymbol{y}$ contains one set of synthetic observations for the whole period of inversion. In theory, the $\mathbf{R}$ matrix accounts for all errors contributing the mismatches between measurements and simulated $\mathrm{CH}_{4}$ mixing ratios at the stations. The $\mathbf{R}$ matrix may be split into two major parts (see Eq. 2): measurement and model variances/covariances. Measurement variances/covariances account for potential instrumental errors, while model variances/covariances group representativity and transport model errors together:

$\mathbf{R}=\mathbf{R}_{\text {measurement }}+\mathbf{R}_{\text {model }}$

Instrumental errors quantify the errors between the mole fractions measured by an instrument and the target mole fractions. For instance, Bergamaschi et al. (2005) assume an instrumental uncertainty of $3 \mathrm{ppb}$ for methane measured at surface stations.

Representation errors account for the misrepresentation of a single spatial and temporal measurement point by a grid box of a 3-D model. Aggregation errors (Kaminski et al., 2001) are also included in representation errors. Transport model errors group together the forcing errors and the model errors. Forcing errors represent the contribution of the errors included in the reanalysis/analysis fields which drive the CTMs, while model errors quantify uncertainties in the physical processes calculated by the CTM (convection, diffusion, advection, etc.).

Here, $\mathbf{R}$ is considered to be diagonal (no covariances) with variances taken from Globalview- $\mathrm{CH}_{4}$ (Globalview- $\mathrm{CH} 4$, 2009). Errors in Globalview- $\mathrm{CH}_{4}$ are computed at each site as the residual standard deviation (RSD) of the measurements on a smooth curve fitting them. We use the RSD at each site as a proxy of the transport model errors, assuming

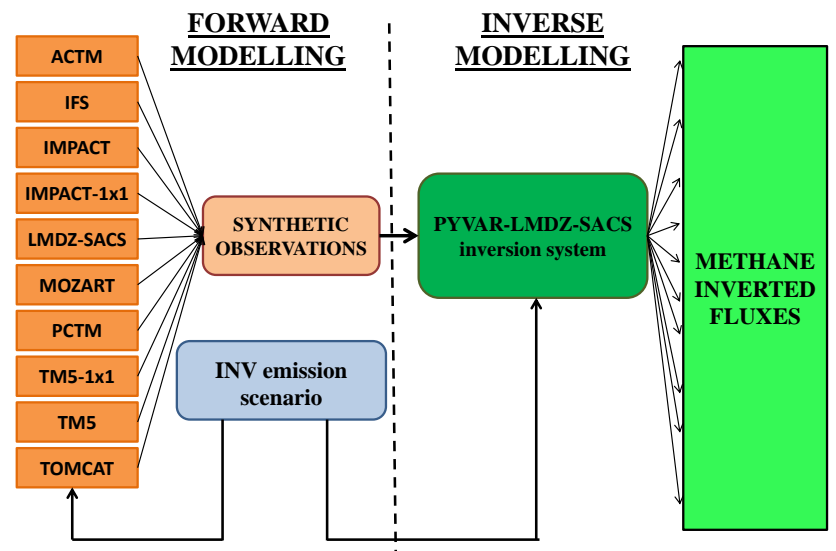

Fig. 1. Schematic showing the methodology of our experiment. Synthetic observations are created from the outputs of TransCom$\mathrm{CH}_{4}$ forward modelling simulations. The TransCom- $\mathrm{CH}_{4}$ INV scenario is used both as the target $\mathrm{CH}_{4}$ flux for forward modelling and as prior fluxes in the inversions. Several $\mathrm{CH}_{4}$ fluxes are derived using the PYVAR-LMDZ-SACS inversion system for 2005.

that the measurement sites with a lot of variability around the mean (e.g. continental sites) are more difficult to model, especially for coarse global models (Geels et al., 2007). This simple approach has been used previously in atmospheric inversions (Bousquet et al., 2006; Yver et al., 2011; Rödenbeck et al., 2003). Errors at stations where Globalview- $\mathrm{CH}_{4}$ data were not available have been interpolated from stations presenting the same characteristics (background/polluted, Northern/Southern Hemisphere, coastal/continental). A detailed discussion on the specification of the $\mathbf{R}$ matrix takes place in Sect. 4. For now, it is important to keep in mind that both forcing and model errors are not explicitly incorporated in the $\mathbf{R}$ matrix of our experiment, which is usually the case in current inversions.

The period of analysis is the year 2005 but all the inversions are run with the same set-up over the extended period of July 2004-July 2006 to avoid edge effects and only keep estimated fluxes for the year 2005.

\subsection{The synthetic observation datasets}

The model outputs from the TransCom- $\mathrm{CH}_{4}$ database are available at selected sites from the most widespread surface networks: Advanced Global Atmospheric Gases Experiment (AGAGE; http://agage.eas.gatech.edu; Prinn et al., 2000), the NOAA Earth Research Laboratory, Global Monitoring Division (ttp://www.esrl.noaa.gov/gmd) and the Japan Meteorological Agency (http://www.jma.go.jp/jma/indexe.html). The synthetic observations are output at the locations shown in Fig. 2, comprising 166 surface stations (including 29 mobile measurements on ships), 6 vertical profiles (aircraft) and 12 tall towers. Some of these sites are continuous in situ stations (red-filled circles). In some other locations, flask 
Table 2. Main transport and sub-grid parameterization schemes (advection, convection and planetary boundary layer (PBL) schemes) of the TransCom models used in this experiment.

\begin{tabular}{llll}
\hline Model name & Advection scheme & Convection scheme & PBL mixing scheme \\
\hline ACTM & Lin and Rood (1996) & Arakawa and Schubert (1974) & Holtslag and Boville (1993) \\
IFS & Hortal (2002) & Bechtold et al. (2008) & Köhler et al. (2011) \\
IMPACT & Lin and Rood (1996) & Rasch and Kristjánsson (1998) & Walton et al. (1988) \\
LMDZ-SACS & Leer (1977); Hourdin and Armengaud (1999) & Tiedtke (1989) & Laval et al. (1981) \\
MOZART & Lin and Rood (1996) & Zhang and McFarlane (1995) & Holtslag and Boville (1993) \\
PCTM & Lin and Rood (1996) & similar to Tiedtke (1989) & Louis (1979) for stable, Lock et al. (2000) for unstable \\
TM5 & Russell and Lerner (1981) & Tiedtke (1989) & Louis (1979); Holtslag and Moeng (1991) \\
TOMCAT & Prather (1986) & Tiedtke (1989) & Holtslag and Boville (1993) \\
\hline
\end{tabular}
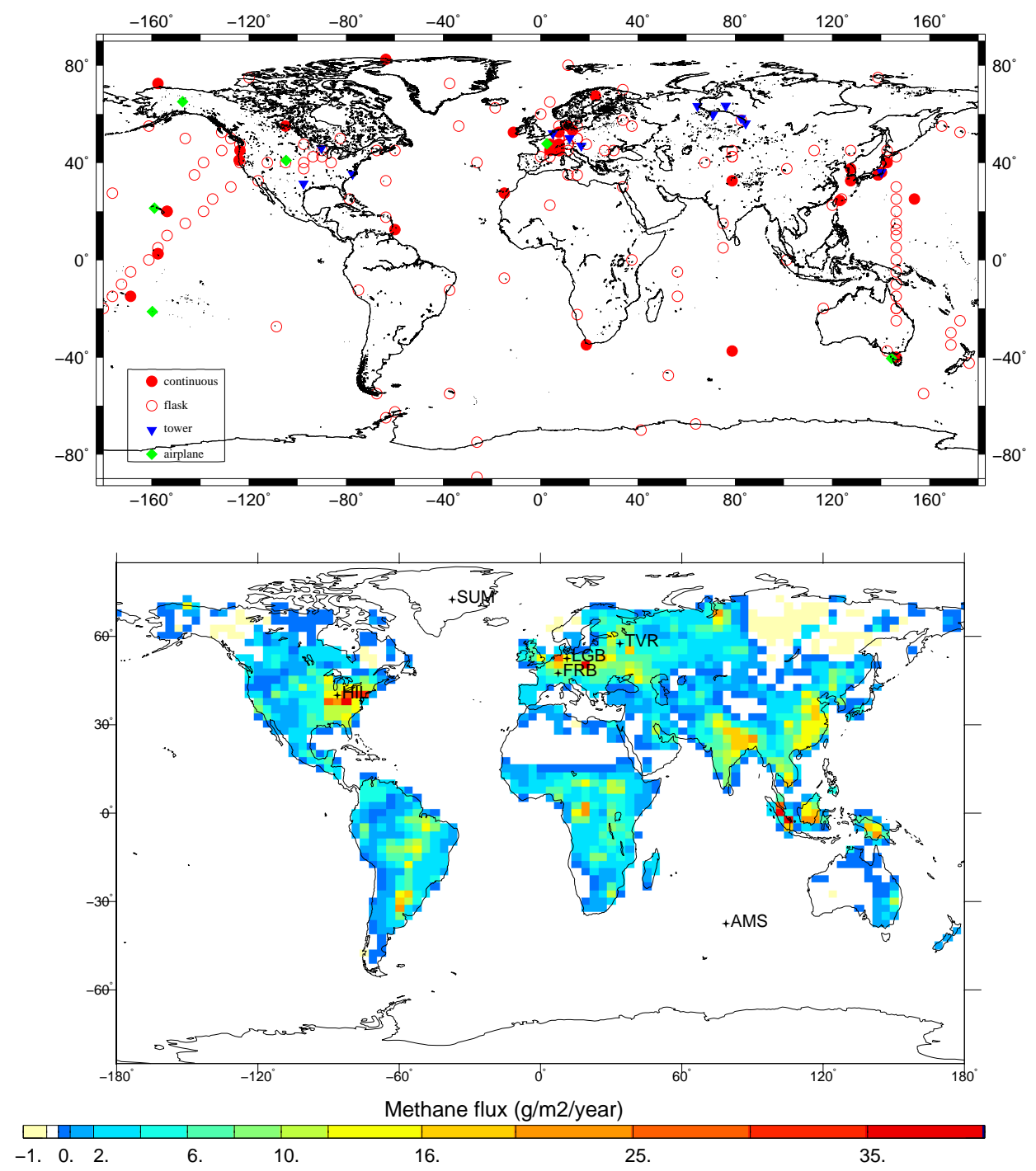

Fig. 2. Geographical representation of the two main inversion components: atmospheric constraint locations (top) and the INV emission scenario (bottom).

samples are collected on a weekly basis (empty red circles). The blue triangles in Fig. 2 show the locations of tall towers and the green diamonds show where aeroplane measurements were taken. For continuous stations, daily means have been computed to be assimilated in the PYVAR inversion framework. In order to mimic realistic sampling strategies, 4 data per month are randomly chosen for each flask site. Following the approach that is often taken when real 


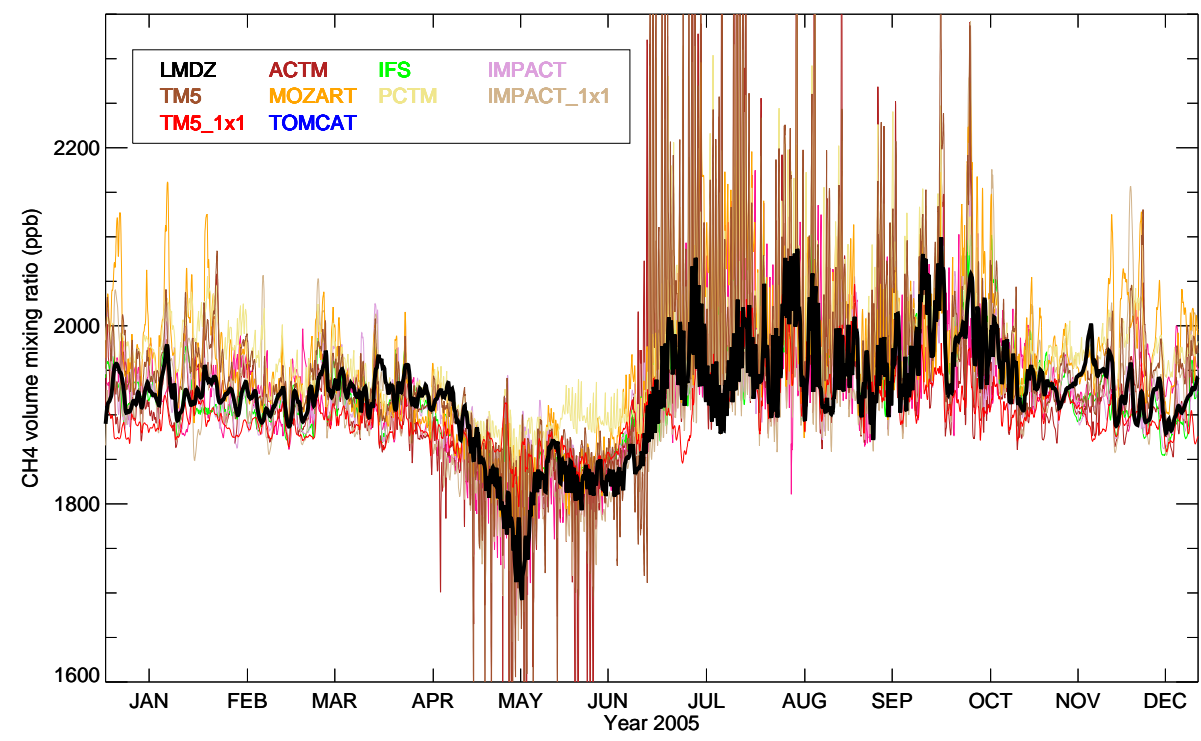

Fig. 3. Time series of daily $\mathrm{CH}_{4}$ mixing ratio at Karasevoe $\left(58.25^{\circ} \mathrm{N}, 82.40^{\circ} \mathrm{E}\right)$ for 2005 . Each TransCom model is represented by a specific colour, while LMDZ-SACS is represented by the black line.

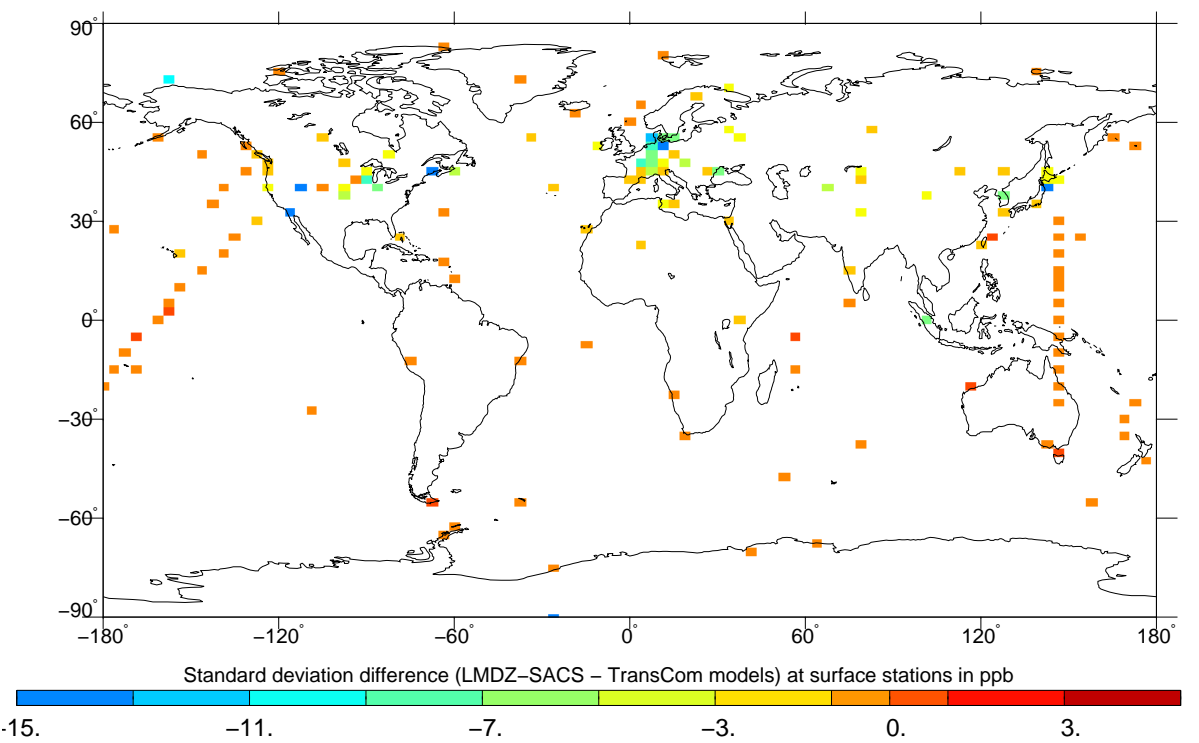

Fig. 4. Map of the differences in the "synoptic" standard deviation (STD) computed for $\mathrm{CH}_{4}$ mixing ratio simulated by LMDZ-SACS and TransCom models at surface stations ( $\sigma_{\text {LMDZ-SACS }}-\overline{\sigma_{\text {TransCom }}} ; \overline{\sigma_{\text {TransCom }}}$ is the average of all TransCom models STD). The synoptic STD difference is expressed in ppb.

observations are used (e.g. Peylin et al., 2005), high altitude ( $1500 \mathrm{~m}$ a.s.l. - metres above sea level) flask measurements are used only in the early morning (07:00 LT) because during the day, due to growing planetary boundary layer, these sites could be influenced by sources and air flows from the neighbouring valleys that may not be resolved by the TransCom models. Towers are considered as continuous stations, from which daily averages are calculated. Two afternoon flights per week are considered for every aeroplane site, on a random basis. When several measurements are available in the same grid box, only the observation located at the highest altitude is kept in the inversion.

We performed reference inversions using an ideal future network (NET1), which contains 166 continuous surface stations. In this network, we assume that all flask sampling sites become continuous. Indeed, if the efforts and the funding to develop and maintain surface networks are preserved (Houweling et al., 2012), more continuous stations should appear around the world in the next years, supplying very valuable information for inversions (Law et al., 2002). No 
information on the $\mathrm{CH}_{4}$ vertical distribution provided by tall towers or by aeroplanes are taken into consideration in the reference inversions.

However, because inversions are highly sensitive to the measurements sampled within the PBL (Geels et al., 2007), two other networks are tested (Fig. 2): a present-day surface network (NET2) with flask sampling sites (empty red circles) and continuous surface stations (filled red circles), and an extension of NET2 that includes aeroplane and tower data (NET3). The differences between the NET2 and NET3 estimates provide information on the contribution of PBL and tropospheric data to $\mathrm{CH}_{4}$ flux estimates. The results are presented in Sect. 3.2 for NET1, and sensitivity tests using NET2 and NET3 are analysed in Sect. 3.4.

\section{Results}

\subsection{Transport model discrepancies in forward modelling}

Differences in the simulated $\mathrm{CH}_{4}$ mixing ratios by the 10 TransCom models (Patra et al., 2011) can provide insights that could help in understanding the inversion results (Sect. 3.2). As mentioned in Sect. 2, differences in the $\mathrm{CH}_{4}$ mixing ratio distributions given by the $10 \mathrm{CTMs}$ are only due to differences in the meteorology (reanalysis fields) and in the modelling of the atmospheric transport (advection schemes, sub-grid scale parameterizations, horizontal and vertical resolutions). In this synthetic experiment, methane mixing ratios simulated by LMDZ-SACS are considered to be the target and we analyse the spread of other models around LMDZ-SACS.

\subsubsection{Synoptic variability}

Large differences in the seasonal cycle and synoptic-scale variations of simulated $\mathrm{CH}_{4}$ mixing ratios are observed at continental sites, as illustrated at Karasevoe station $\left(58.25^{\circ} 23 \mathrm{~N} ; 82.40^{\circ} 23 \mathrm{E}\right.$, Russia) (Fig. 3). For this station, located close to high emission zones in summer, differences in the magnitude of the seasonal cycle can be related to differences in the vertical transport within the PBL, which is primarily simulated by sub-grid scale parameterizations. Phase differences observed in the synoptic variations at Karasevoe can directly be related to the differences in the meteorological fields used by the models. Indeed, CTMs using similar meteorological drivers are found to be more highly correlated with each other than with other models. For instance, methane time series simulated by IFS using ERAinterim reanalysis are highly correlated to TM5 $1 \times 1$ and TM5, which use the ERA-interim reanalysis as well, with linear Pearson correlation coefficients of 0.92 and 0.84 respectively, whereas the average correlation of IFS with other models is approximately 0.68 .
To more precisely quantify the magnitude of the variability between the synthetic observations and the target $\mathrm{CH}_{4}$ mixing ratios generated by LMDZ-SACS, we compute the differences between the $\mathrm{CH}_{4}$ mole fraction standard deviation (STD) of LMDZ-SACS and STD of other TransCom models at all surface stations of NET1 (Sect. 2.4). Discrepancies in the modelling of both the seasonal cycle amplitude and the synoptic variability contribute to STD differences. Hereafter, we call "synoptic STD" the STD related to synoptic variability when the seasonal cycle is removed from the time series. The analysis of STD at 16 continental stations shows that synoptic variability dominates over seasonal variability: STD related to synoptic variability (respectively related to seasonal cycle) are $87 \%$ (respectviely $42 \%$ ) of the total STD values. Moreover, synoptic differences can be converted into expectations for the estimates by inverse modelling: TransCom models simulating a larger synoptic variability (and consequently higher concentration peaks) than LMDZ-SACS at some stations are expected to give higher inverted fluxes within the area impacting these stations.

The map of synoptic STD differences between LMDZSACS and the average of all the TransCom models $\left(\sigma_{\text {LMDZ-SACS }}-\overline{\sigma_{\text {TransCom }}} ; \overline{\sigma_{\text {TransCom }}}\right.$ being the average of all TransCom model "synoptic STD", $\left.\sigma_{(\text {TransCom model })}\right)$ is presented in Fig. 4 at stations of NET1. At first glance, a strong contrast is found between continental stations and stations with a dominant oceanic influence. On the one hand, synoptic STD differences close to zero ppb (or slightly positive) are found at oceanic stations of the Southern Hemisphere (e.g. AMS station in the Indian Ocean). On the other hand, strong negative values of synoptic STD differences are found for continental stations of the Northern Hemisphere, suggesting that amplitude of synoptic variations simulated by LMDZ-SACS are smaller, on average, than those simulated by the other TransCom models at these stations. Indeed, a previous study (Geels et al., 2007) has mentioned that LMDZ, as well as some other global models, underestimates synoptic variations of $\mathrm{CO}_{2}$ concentrations and that the fast boundary layer ventilation of LMDZ could explain the small surface concentration peaks.

Stations located in the vicinity of methane sources appear to be associated with strong negative synoptic STD difference values. For instance, TVR $\left(57.50^{\circ} \mathrm{N} ; 33.75^{\circ} \mathrm{E}\right.$, Eastern Europe), LGB (52.8 ${ }^{\circ} \mathrm{N} ; 10.8^{\circ} \mathrm{E}$, Europe), FRB $\left(47.50^{\circ} 23 \mathrm{~N}\right.$; $7.50^{\circ} \mathrm{E}$, Europe $)$ and $\mathrm{HIL}\left(40.1^{\circ} \mathrm{N} ; 87.9^{\circ} \mathrm{W}\right.$, east coast of the USA) are exposed to high sources of methane from the INV scenario (see Fig. 2) and the mean synoptic STD differences at these stations are respectively $-20,-23,-35$ and $-15 \mathrm{ppb}$. Indeed, small-scale transport processes, such as turbulence in the planetary boundary layer, which may be poorly represented by global CTMs, have a large influence on the mole fractions simulated at stations close to large emission areas. In contrast, stations far from any methane sources are mainly influenced by large scale transport of $\mathrm{CH}_{4}$ signals from remote sources, which produce smaller differences 


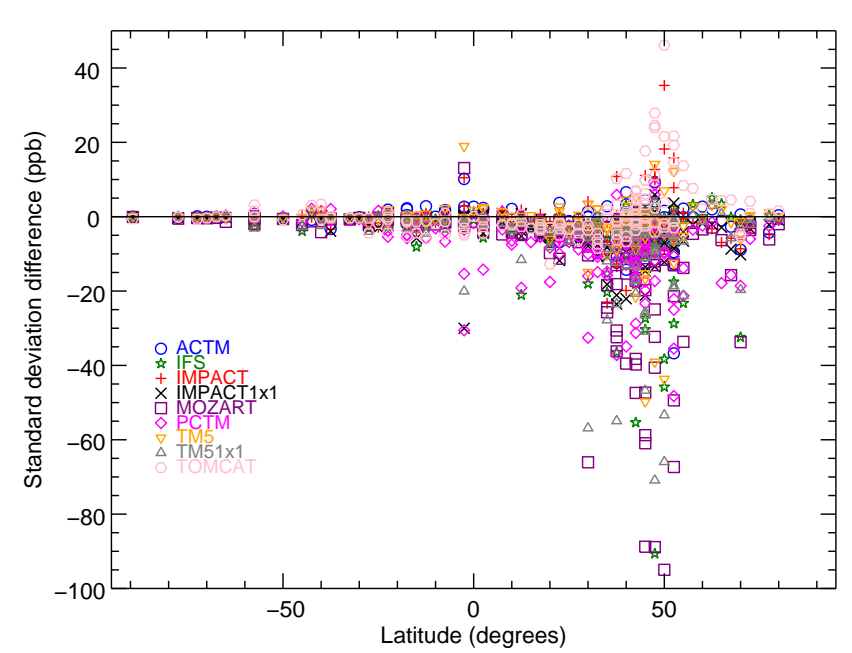

Fig. 5. Latitudinal distribution of the "synoptic" standard deviation (STD) differences between LMDZ-SACS and other TransCom models at all surface stations $\left(\sigma_{\text {LMDZ-SACS }}-\sigma_{(\text {TransCom model })_{i}}\right)$. Each TransCom model is represented by a specific symbol. The STD difference is expressed in ppb.

between models. Stations may also be located either close to, or far from, $\mathrm{CH}_{4}$ sources, depending on the season. Figure 3 shows a high concentrations period (from May to August) at Karasevoe which is completely correlated to emissions from wetlands in this area at this period of the year. The average STD for all models during the high methane emission period is $38 \mathrm{ppb}$, while the STD falls to $15 \mathrm{ppb}$ outside this period. Turbulent mixing in the boundary layer and convection are the main processes acting in this area during the summer period. The more methane is emitted, the more skills in the modelling of turbulent mixing and convection are required to accurately simulate methane mixing ratios, leading to a poorer agreement between models during the summer months.

In order to better analyse the modelling of synoptic variability for each individual TransCom model, we computed the latitudinal distribution of synoptic STD differences at surface stations (Fig. 5). In the Southern Hemisphere, almost no distinction can be made between models: synoptic STD differences are around $0 \mathrm{ppb}$. In the Northern Hemisphere, MOZART, TM5 $1 \times 1$, IFS and PCTM exhibit the largest negative synoptic STD difference values, meaning that these models simulate higher variability than LMDZSACS. On the contrary, TOMCAT is one of the models showing the largest positive difference with LMDZ-SACS. These statements are especially true for continental stations in the Northern Hemisphere. As a consequence, it is expected to find, higher inferred emissions for MOZART, TM5 $1 \times 1$, IFS and PCTM and lower emissions for TOMCAT at least locally (close to monitoring sites) compared to the target INV emission scenario.
The impact of horizontal resolution on the modelling of synoptic variability is detailed in Sect. 3.3.

\subsubsection{Inter-hemispheric (IH) exchange time}

The inter-hemispheric $(\mathrm{IH})$ exchange time is a good indicator with which to analyse large scale transport differences between transport models. The map of mean bias in simulated $\mathrm{CH}_{4}$ mixing ratios at surface stations between LMDZ-SACS and other TransCom models $\left(y_{\text {LMDZ-SACS }}-\overline{y_{\text {TransCom }}}\right)$ reveals negative values at stations in the Northern Hemisphere, meaning that $\mathrm{CH}_{4}$ mixing ratios simulated by LMDZSACS are, on average, lower than those simulated by other TransCom models (Fig. 6). In contrast, positive biases at surface stations in the Southern Hemisphere are found. Using $\mathrm{SF}_{6}$ observations, LMDZ-SACS has been identified to exhibit relatively slow IH exchange, characterized by an exchange time of $1.2 \mathrm{yr}$, which is in the lower range of the ensemble of TransCom models (Patra et al., 2011, Fig. 8). Therefore, compared to the other models, LMDZ-SACS tends to transport methane more quickly from the dominant emission zones of the Northern Hemisphere to the Southern Hemisphere. This fast IH transport produces the inferred negative biases in the north and positive biases in the south. Therefore, one can expect that higher emissions will be necessary over the northern continents, and/or lower emissions over the southern continents when deriving fluxes using LMDZ-SACS, compared to when synthetic observations were taken from the other models.

This finding is robust when looking at individual models and not only at the model average (Fig. 7). For instance, TM5 (orange triangles) shows larger gradients of biases between the stations of the Northern Hemisphere (difference of around $-20 \mathrm{ppb}$ ) and of the Southern Hemisphere (difference of around $+10 \mathrm{ppb}$ ). This is consistent with TM5 having the longest IH exchange time in Patra et al. (2011). As a consequence, using synthetic observations from TM5 in the inversions should increase the IH gradient of emissions, with lower emissions in the Southern Hemisphere and higher emissions in the Northern Hemisphere.

\subsection{Impact of transport model errors on inversions}

Ten variational inversions have been performed, in which methane fluxes were derived using synthetic observations from TransCom- $\mathrm{CH}_{4}$ models (Patra et al., 2011). The same set-up (prior emissions from INV scenario, observation errors, prior errors, etc.) has been used for every inversion (see Sect. 2.3). In order to keep the explanations clear in the following sections, each inversion is called by the name of the CTM used to generate the synthetic observations.

\subsubsection{Global and hemispheric fluxes}

Figure 8 presents the total estimated $\mathrm{CH}_{4}$ fluxes for every inversion at global scale. The blue bars show the global 


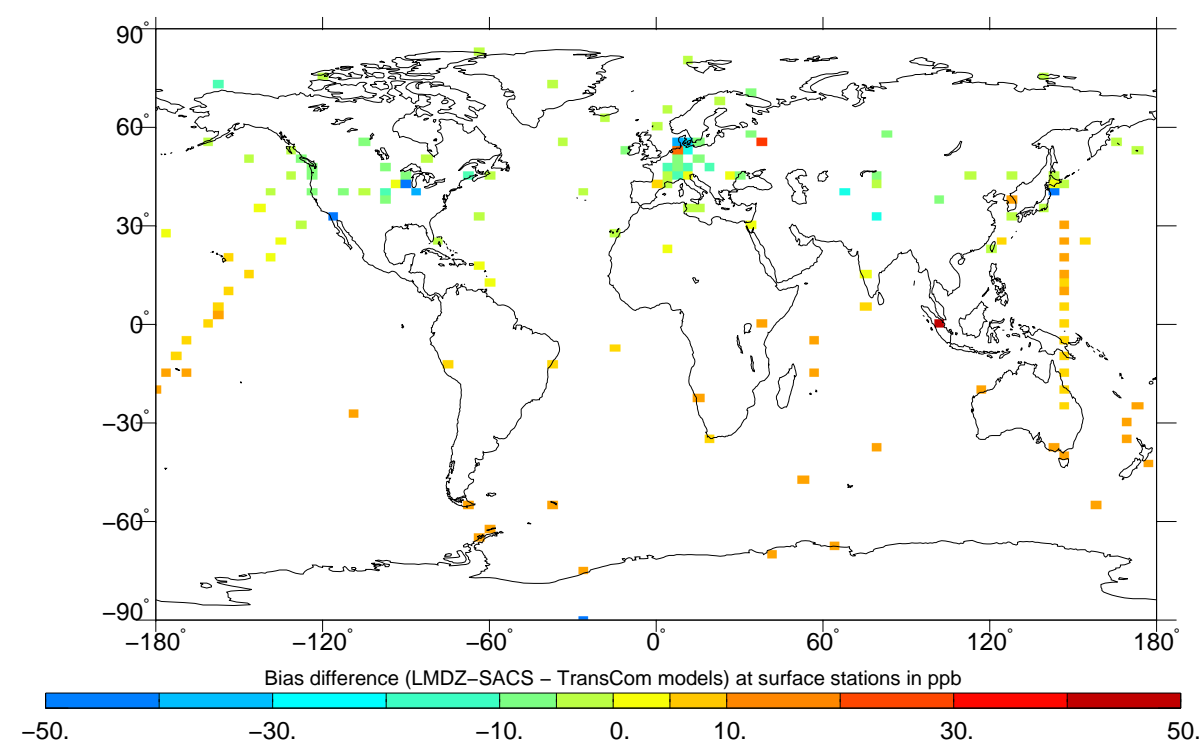

Fig. 6. Bias between $\mathrm{CH}_{4}$ mixing ratios simulated by LMDZ-SACS and other TransCom models $\left(y_{\mathrm{LMDZ}}-\overline{y_{\text {TransCom }}}\right.$; $\overline{y_{\text {TransCom }}}$ is the average of $\mathrm{CH}_{4}$ mixing ratios simulated by all TransCom models) at surface stations. The bias is expressed in $\mathrm{ppb}$.

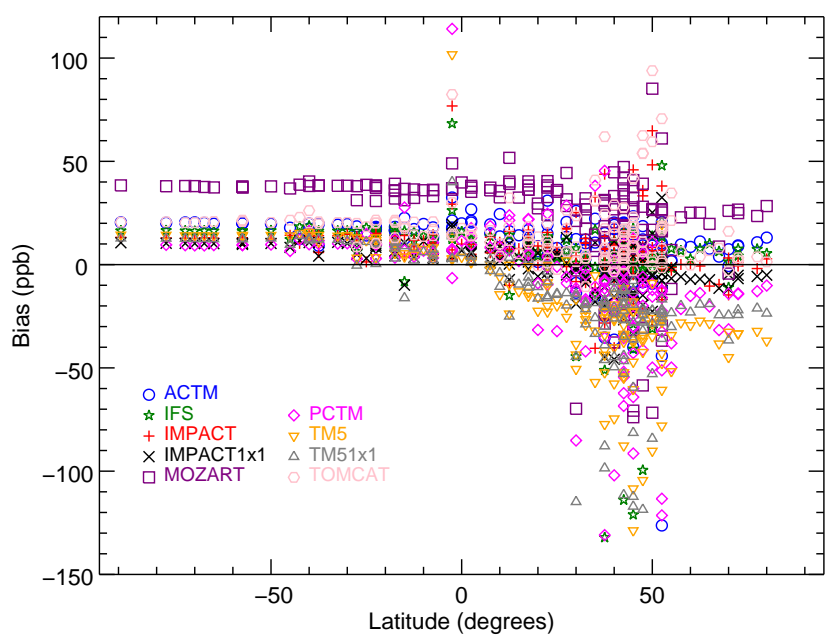

Fig. 7. Latitudinal distribution of the bias between $\mathrm{CH}_{4}$ mixing ratios simulated by LMDZ-SACS and TransCom models $\left(y_{\mathrm{LMDZ}}-y_{(\text {TransCom model })_{i}}\right)$ at all surface stations. Each TransCom model is represented by a specific symbol. The bias is expressed in $\mathrm{ppb}$.

$\mathrm{CH}_{4}$ estimates for TransCom models and the red line points out the value of the target global $\mathrm{CH}_{4}$ flux $\left(523 \mathrm{Tg} \mathrm{yr}^{-1}\right.$, INV scenario). The inferred $\mathrm{CH}_{4}$ fluxes for 2005 range from $523 \mathrm{Tg} \mathrm{yr}^{-1}$ (MOZART inversion) to $550 \mathrm{Tg} \mathrm{yr}^{-1}$ (PCTM inversion), with an average of $538 \mathrm{Tg} \mathrm{yr}^{-1}$. These results show that discrepancies in the modelling of atmospheric transport among the CTMs are responsible for a spread of $27 \mathrm{Tg} \mathrm{yr}^{-1}$ (5\% of the target flux) on the inverted fluxes at the global scale. For comparison, the annual global methane emissions from rice paddies are estimated to be $37.5 \mathrm{Tg} \mathrm{yr}^{-1}$

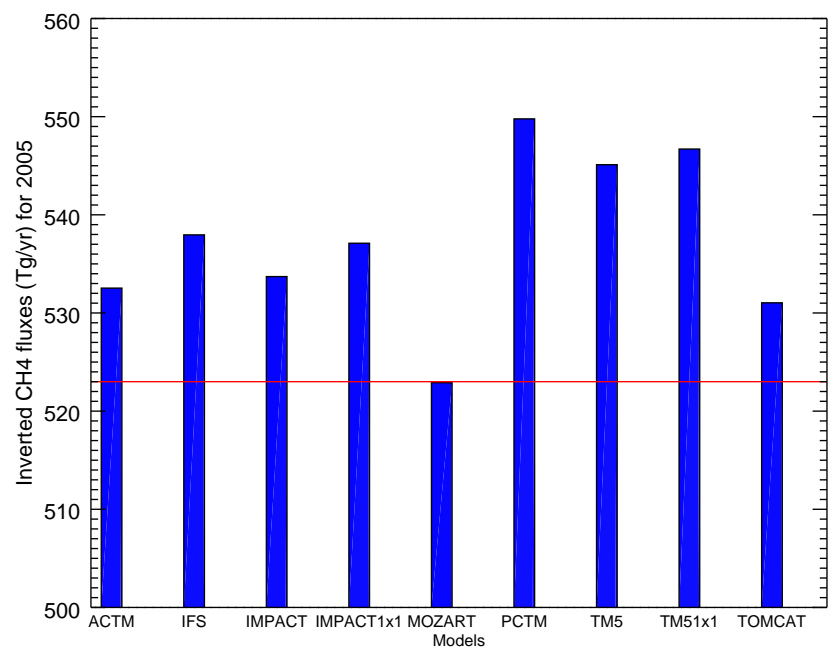

Fig. 8. Inverted $\mathrm{CH}_{4}$ fluxes for every TransCom model at the global scale in 2005. The red line represents the value of the target methane flux at the global scale (523 Tg in 2005 - INV scenario).

in 2008 (EDGAR-v4.2, 2011). Global methane emissions from biofuel and biomass burning have been estimated to be $36 \mathrm{Tg} \mathrm{yr}^{-1}$ in the late nineties (Andreae and Merlet, 2001; van der Werf et al., 2010). Likewise, EDGAR-v4.2 (2011) infers methane emissions of $19.8 \mathrm{Tg} \mathrm{yr}^{-1}$ from European countries of the OECD in 2005. Consequently, in order to detect changes in methane emissions from a large region or to estimate global emissions from some specific process, the impact of transport model errors on the inverse estimates is currently an important limitation. 
Table 3. Estimates of hemispheric methane fluxes in teragrams of methane per year $\left(\mathrm{Tg} \mathrm{yr}^{-1}\right)$ for every TransCom model inversion. Inverted fluxes in the Northern $(\mathrm{NH})$ and in the Southern Hemisphere (SH) are presented in the first two columns. The interhemispheric gradient ( $\mathrm{NH}$ estimate- $\mathrm{SH}$ estimate) is shown in the third column.

\begin{tabular}{lccc}
\hline & $\begin{array}{c}\text { Northern } \\
\text { Hemisphere }\end{array}$ & $\begin{array}{c}\text { Southern } \\
\text { Hemisphere }\end{array}$ & $\begin{array}{c}\text { Difference } \\
\text { NH-SH }\end{array}$ \\
\hline Target flux & 368 & 155 & 213 \\
ACTM & 391 & 142 & 249 \\
IFS & 388 & 150 & 238 \\
IMPACT & 385 & 148 & 237 \\
IMPACT $1 \times 1$ & 385 & 152 & 233 \\
MOZART & 378 & 145 & 233 \\
PCTM & 410 & 140 & 270 \\
TM5 & 429 & 116 & 313 \\
TM5 $1 \times 1$ & 414 & 133 & 281 \\
TOMCAT & 387 & 144 & 243 \\
\hline
\end{tabular}

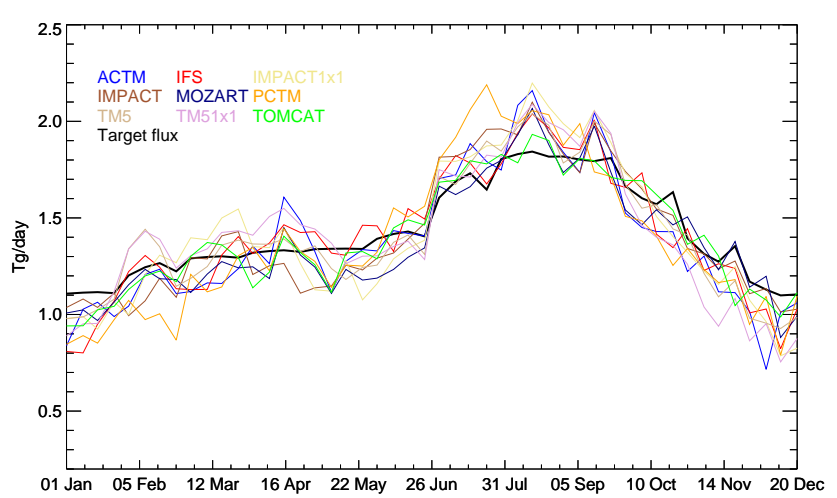

Fig. 9. Time series of weekly estimated $\mathrm{CH}_{4}$ fluxes at the global scale for every TransCom model. The black line represents the time series of the target flux.

It is noteworthy to mention that all inversions have derived higher or equal total fluxes at the global scale compared to the target flux. Indeed, as previously stated, the faster IH transport exhibited by the LMDZ-SACS model, compared to other models, yields higher average emissions in the Northern Hemisphere $\left(+29 \mathrm{Tg} \mathrm{yr}^{-1}\right)$ and lower average emissions $\left(-14 \mathrm{Tg}_{\mathrm{yr}} \mathrm{C}^{-1}\right)$ in the Southern Hemisphere. This leads to a global increase of $15 \mathrm{Tg} \mathrm{yr}^{-1}$ in order to match the concentrations of the synthetic observations. Table 3 summarizes the estimates in the two hemispheres and the difference in emissions between the Northern and the Southern Hemisphere for each model. As expected, TM5 derives the highest estimates in the Northern Hemisphere and the lowest estimates in the Southern Hemisphere, which is consistent with the slower IH exchange time exhibited for TM5 compared to LMDZ-SACS.

Time series of estimated $\mathrm{CH}_{4}$ fluxes at the global scale (Fig. 9) show similar seasonal variations for all the CTMs, with a peak in methane emissions during the boreal summer. The overlaid black line represents the target methane flux time series. Maxima in the estimated fluxes reach $0.3 \mathrm{Tg} \mathrm{day}^{-1}$, which is about half of the amplitude of the seasonal cycle $\left(0.7 \mathrm{Tg}_{\mathrm{day}}{ }^{-1}\right)$. The target flux is in the higher part of estimated emissions range during boreal winter and in the lower part during boreal summer. Consequently, the amplitude of the estimated $\mathrm{CH}_{4}$ flux seasonal cycle is, on average, twice as large $\left(\sim 1.4 \mathrm{Tg}_{\mathrm{day}}{ }^{-1}\right)$ as that of the target flux at the global scale. Indeed, the fast IH exchange time of LMDZ-SACS accentuates the derived seasonal cycle by increasing emissions in the Northern Hemisphere during boreal summer and decreasing emissions in the Southern Hemisphere during austral summer.

\subsubsection{Regional fluxes}

Figure 10 shows estimated $\mathrm{CH}_{4}$ fluxes for seven continental regions (Europe, North America, Asia, South America, Africa, Oceania and Boreal Eurasia). The spread of the inverted regional fluxes quantifies the impact of transport model errors on the estimation of methane fluxes inferred by atmospheric inversions at regional scales. Transport model errors produce much larger relative uncertainties on the methane emission estimates at the regional scale than at the global scale: from $23 \%$ for Europe $\left(16 \mathrm{Tg} \mathrm{yr}^{-1}\right)$ to $48 \%$ for South America (35 $\mathrm{Tg} \mathrm{yr}^{-1}$ ). The spread in Africa is quite large $\left(25 \mathrm{Tg} \mathrm{yr}^{-1}\right)$ with estimates split in two groups: inversions deriving emissions around $95 \mathrm{Tg} \mathrm{yr}^{-1}$ (ACTM, TOMCAT and TM5) and those around $75 \mathrm{Tg} \mathrm{yr}^{-1}$ (IFS, IMPACT, IMPACT $1 \times 1$, MOZART, PCTM and TM5 $1 \times 1$ ) for 2005 .

Some characteristics of the TransCom models highlighted in Sect. 3.1 have a direct impact on the estimates at continental scale. For instance, the impact of the particularly fast $\mathrm{IH}$ exchange time of LMDZ-SACS is noticeable at continental scale. Indeed, for the majority of models, inversions derive higher estimates than the target fluxes in continental regions of the Northern Hemisphere (especially for North America). On the contrary, derive emissions from Southern Hemisphere continental regions tend to be lower than the target fluxes (especially for Oceania). This characteristic is particularly obvious for TM5, which has a particularly slow IH exchange time in Patra et al. (2011).

The spread of fluxes derived for North America is quite large $(37 \%)$. PCTM shows particularly high fluxes in this region, a feature which may be related to the propensity for PCTM to simulate relatively high concentration peaks at continental stations, especially in North America (see Sect. 3.1.1). On the other hand, TOMCAT, which simulates smaller synoptic variability than LMDZ-SACS, has estimates in Europe and in North America that are at the lower end of the derived estimates. These results confirm that discrepancies in synoptic variability of $\mathrm{CH}_{4}$ concentrations have an impact on the flux estimates in regions with many continental stations in the vicinity of large emission areas, 


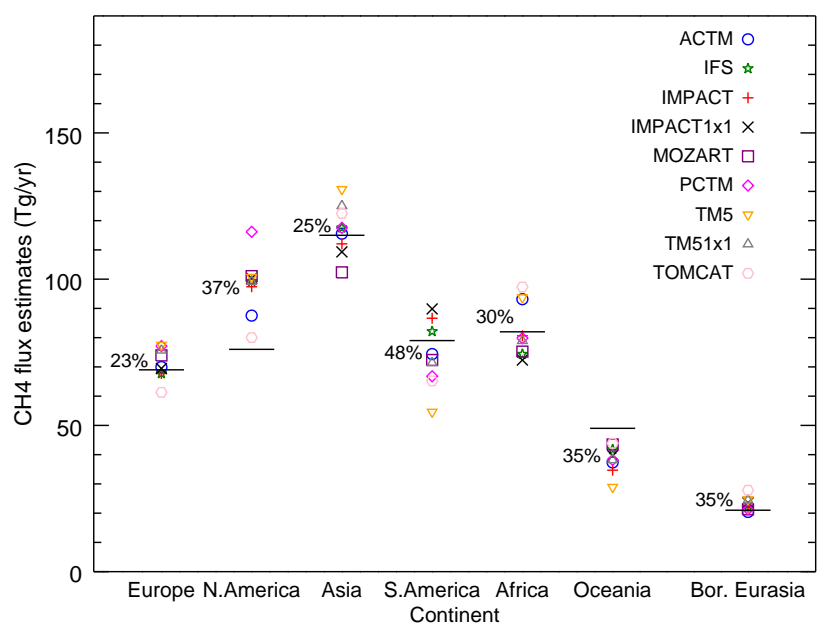

Fig. 10. Inverted $\mathrm{CH}_{4}$ fluxes at regional scale. Seven continental regions are displayed here (Europe, North America, Asia, South America, Africa, Oceania and Boreal Eurasia). Every symbol shows the estimated value for a specific TransCom model and for a specific region. The percentage indicates the spread of the estimates as a whole for every region. The black lines show the target methane regional estimates.

where modelling of synoptic variability may be very different among CTMs (Sect. 3.1.1).

Time series of weekly methane flux estimates are presented for one region of the Northern Hemisphere (Western Europe) and one region of the Southern Hemisphere (Oceania; Fig. 11). The spread in estimated methane fluxes is much higher at regional than global scales (see Sect. 3.2.1), relative to the amount of methane emitted from these regions. The mean flux variability in Western Europe has a magnitude more than twice as high $\left(\approx 0.1 \mathrm{Tg}^{\mathrm{day}}{ }^{-1}\right)$ as the seasonal cycle of the target flux $\left(\approx 0.04 \mathrm{Tg} \mathrm{day}^{-1}\right)$. Moreover, the distribution of flux estimates in Western Europe is slightly larger during winter months than during summertime. Indeed, extratropical storm tracks, which directly influence atmospheric conditions in Western Europe, are more active in winter than in summer. Consequently, more uncertainty is expected in wind fields provided by weather forecast centers during this period. Differences in the modelling of shallow winter boundary layers can also contribute to the large variability among models.

The amplitude of the estimated flux variability in Oceania is less pronounced because the magnitude of methane emissions is much lower than in Western Europe. However, again, the impact of the IH transport is clearly seen in the inverted fluxes: the target flux in Oceania is in the upper range of the estimated $\mathrm{CH}_{4}$ fluxes throughout the time series, in agreement with the lower inverted emissions in the Southern Hemisphere regions, as would be expected following Sect. 3.1.2.

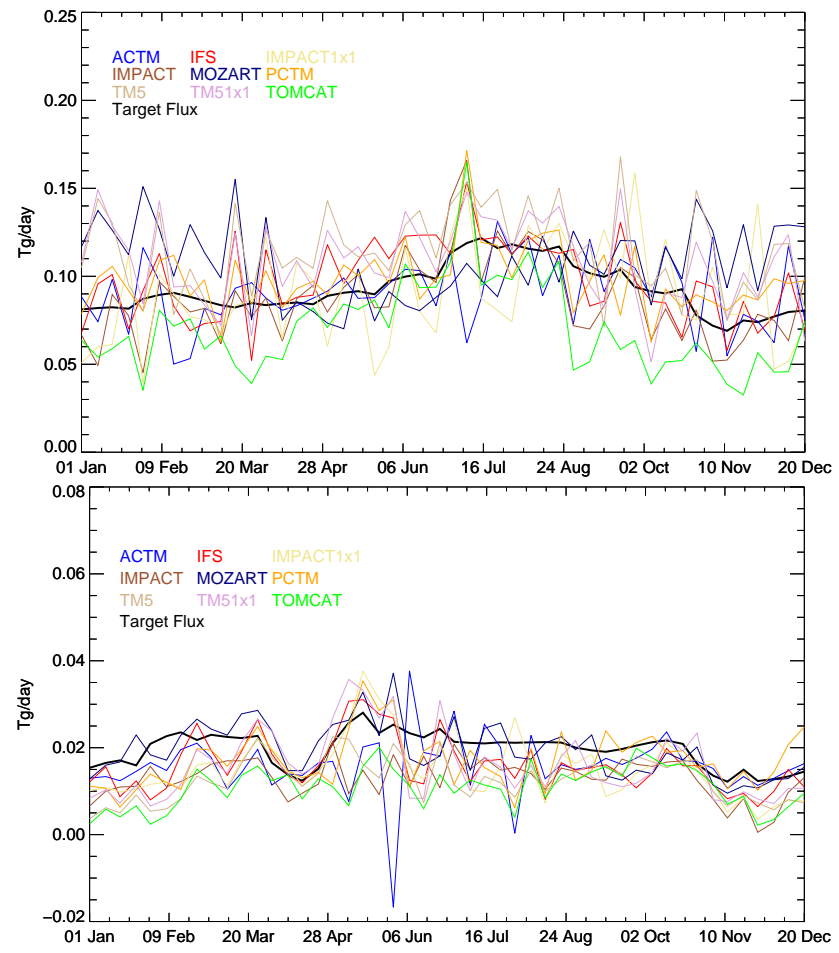

Fig. 11. Time series of weekly estimated $\mathrm{CH}_{4}$ fluxes in $\mathrm{Tg}$ per day for Western Europe (top) and Oceania (bottom). The black line represents the time series of the target flux.

\subsubsection{Spatial distribution of inverted fluxes}

This section examines one of the advantageous aspects of the inversion using the variational approach, i.e. the ability to infer optimal fluxes at grid-box scale.

Figure 12 displays the maps of the differences between the target $\mathrm{CH}_{4}$ fluxes (INV scenario) and inverted $\mathrm{CH}_{4}$ fluxes for each model at the grid-scale. A positive (negative) difference, from light to dark red colours (from light to dark blue), means that fluxes estimated in inversions using synthetic observations are larger (smaller, respectively) compared to the target $\mathrm{CH}_{4}$ fluxes.

When compared to the target flux field, we find groups of inversions that have coherent spatial patterns in the derived flux anomaly in some regions. For example, most inversions derive lower emissions than the INV scenario in South America, more or less around a north-south track. It is very clear for TOMCAT, PCTM and TM5. Some other models (IMPACT $1 \times 1$, IFS and TM5 $1 \times 1$ ), characterized by higher horizontal resolution, show a dipole of emissions probably associated with the simulated position of the ITCZ (Intertropical Convergence Zone): they derive higher emissions than the target flux in the north of South America and lower fluxes in the south. In other regions, all inversions derive mostly the same sign for emission changes, compared to the target, but their geographical distribution within the 


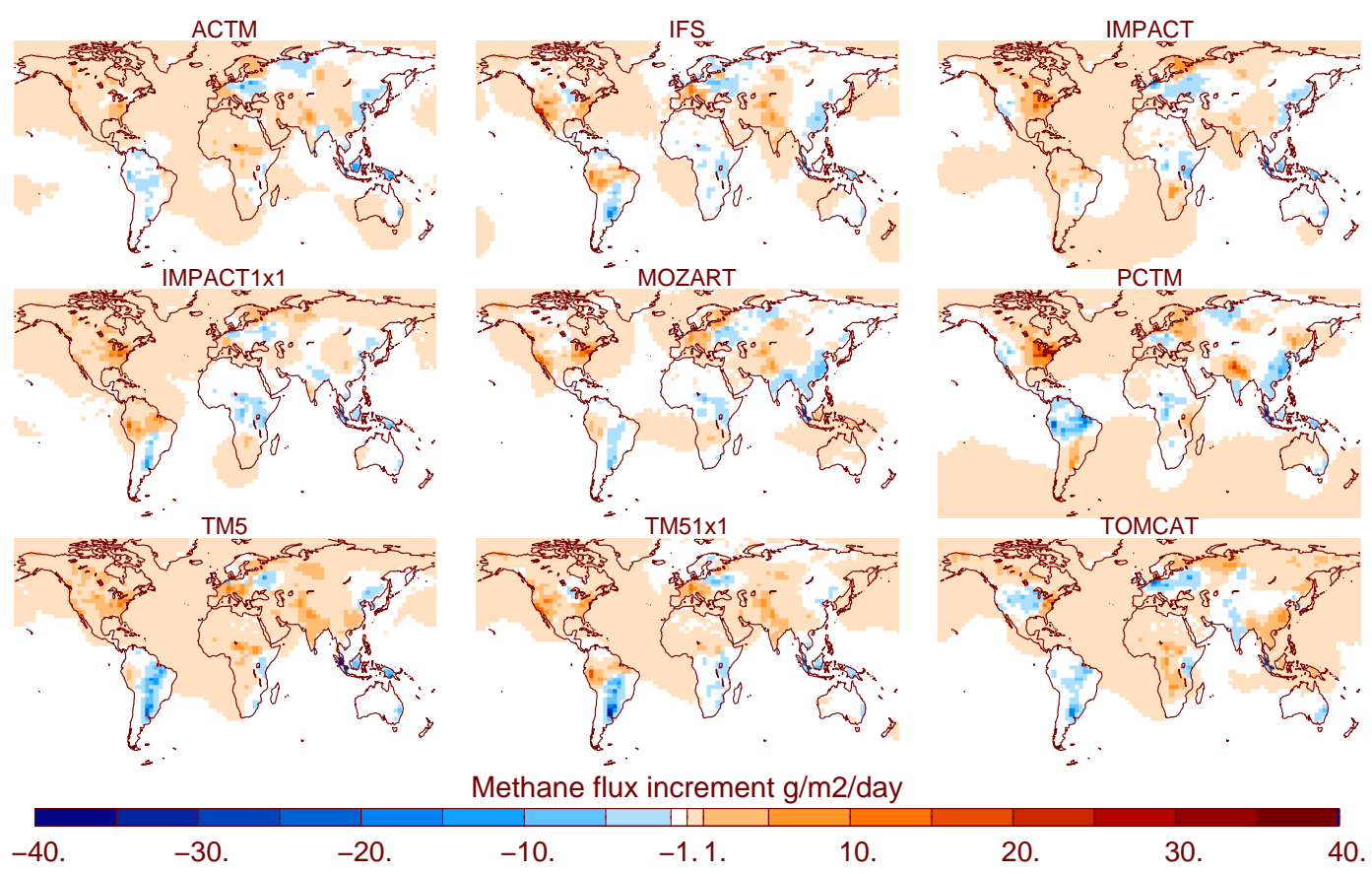

Fig. 12. Panel showing the differences between $\mathrm{CH}_{4}$ analysed fluxes and target fluxes $\left(X_{\text {TransCom }}^{\text {analysed }}-X_{\text {target }}\right)$ at grid box scale for every TransCom model. The flux differences are expressed in $\mathrm{g} \mathrm{m}^{-2} \mathrm{day}^{-1}$.

region may be very different depending on the model. For example, in North America most inversions derive higher emissions than the target methane emission. However, higher emissions are derived on the east coast of the United States by IMPACT, IMPACT $1 \times 1$ and PCTM, on the west coast by IFS and TM5 $1 \times 1$, and on both coasts of the United States by MOZART and TM5.

In Asia, Europe and Africa it is difficult to distinguish any pattern in the inferred emissions. It is important to note that IFS and TM5 $1 \times 1$ have a similar spatial distribution of inverted fluxes probably related to the fact that they use the same meteorological fields and have a very similar horizontal resolution.

To synthetize the impact of transport model errors at the grid scale, Fig. 13 shows the map of the spread between all methane inverse estimates as a percentage of the target flux. The regions previously identified with large discrepancies in the different methane estimates are highlighted here with grid cell differences up to $150 \%$ of the target flux. For instance, we clearly see two patterns with large spreads in South America, owing to the emission dipole mentioned in the previous analysis. The west coast of the United States and the poorly constrained region of Eastern Siberia also show a large spread. We also see larger spreads in the grid cells surrounding some stations strongly constraining the inverse system. This is the case, for instance, at Cape Grim $\left(40.68^{\circ} \mathrm{S}\right.$; $144.68^{\circ} \mathrm{E}$, Australia, Oceania) and at Mount Kenya $\left(0.06^{\circ} \mathrm{S}\right.$; $37.30^{\circ} \mathrm{E}$, Kenya, Africa).

\subsection{Sensitivity to the model horizontal resolution}

The TM5 and IMPACT simulations included higher resolution versions (TM5 $1 \times 1$ and IMPACT $1 \times 1$ ) which allow the investigation of the impact of an increasing horizontal resolution on the derived methane fluxes.

First, STD due to synoptic variability for the highresolution version of TM5 and IMPACT are, on average, higher at continental stations of the Northern Hemisphere (see Fig. 5). Indeed, one can assume that the increase in horizontal resolution leads to less smoothing of the high concentration gradients in the high methane emission regions. It is found that STD values related to synoptic variability are, on average, $15 \mathrm{ppb}$ higher for TM $51 \times 1$ than for TM5 and $9 \mathrm{ppb}$ higher in the case of IMPACT $1 \times 1$ compared to IMPACT, which could have a direct impact on the global estimate by increasing the emissions of TM5 $1 \times 1$ and IMPACT $1 \times 1$ compared to TM5 and IMPACT.

Concerning inversion results, there is only a $2 \mathrm{Tg} \mathrm{yr}^{-1}$ difference between estimates of TM5 $1 \times 1\left(547 \mathrm{Tg} \mathrm{yr}^{-1}\right)$ and TM5 $\left(545 \mathrm{Tg} \mathrm{yr}^{-1}\right)$ inversions and $3 \mathrm{Tg} \mathrm{yr}^{-1}$ between estimates of IMPACT $1 \times 1 \quad\left(537 \mathrm{Tg} \mathrm{yr}^{-1}\right)$ and IMPACT $\left(534 \mathrm{Tg} \mathrm{yr}^{-1}\right)$ inversions at the global scale. The increase of the global $\mathrm{CH}_{4}$ emission estimates between the high and the low resolution versions of the CTMs is in agreement with the previous analysis of STD values. Nevertheless, in Patra et al. (2011) (see their Fig. 8), it is shown that the IH exchange time of TM5 $1 \times 1(\sim 1.60 \mathrm{yr}$ in 2005$)$ is faster than for TM5 ( $\sim 1.75 \mathrm{yr}$ in 2005$)$ which should result in a global 


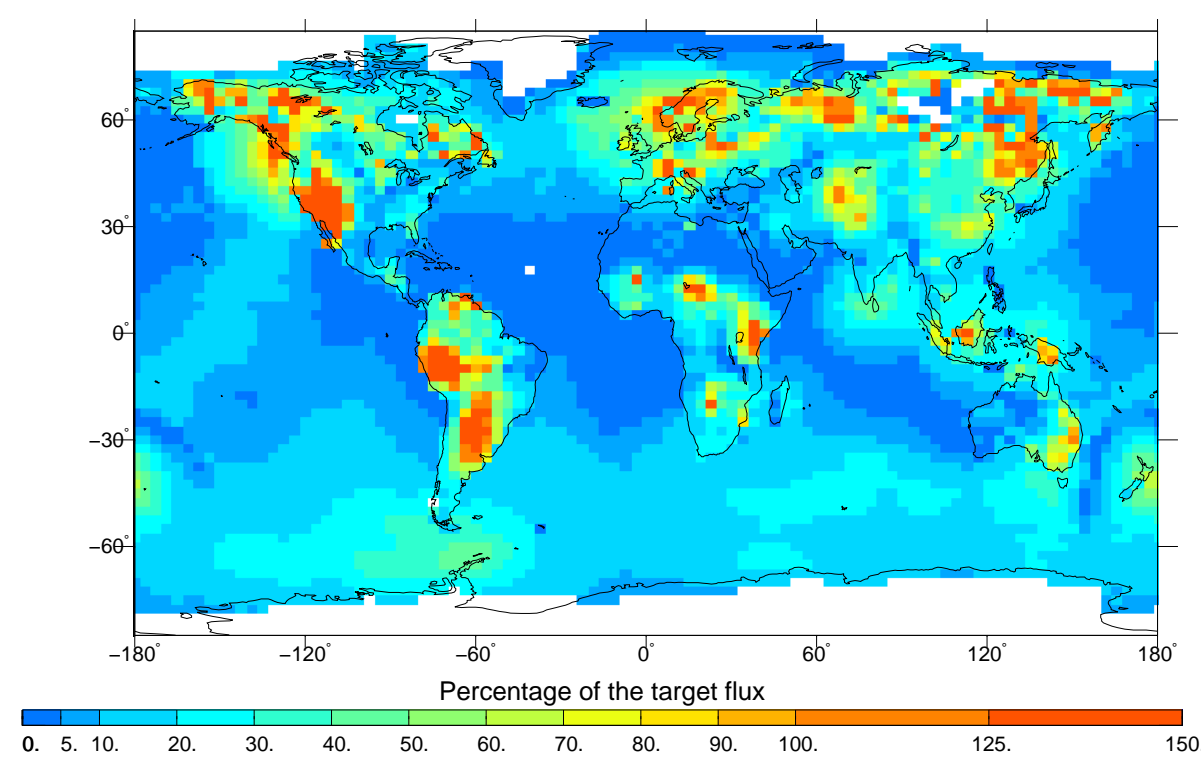

Fig. 13. Map of the spread of methane inverse estimates at the model grid-scale as a percentage (\%) of the target flux (INV emission scenario).

estimate closer to the target global estimate. As a consequence, the impact of synoptic variability on the global flux is probably balanced by the impact of IH exchange, which results in only a slight increase of the global flux derived by TM5 $1 \times 1$ compared to TM5. The results are less clear for IMPACT/IMPACT $1 \times 1$ because the magnitude of these two effects (amplitude of synoptic variability and IH exchange) in the forward modelling study are smaller than for TM5 and TM5 $1 \times 1$.

The impact of horizontal resolution on the estimated methane fluxes may be relatively different at continental scales. Estimated fluxes in Europe and in North America are very close for TM5/TM5 $1 \times 1$ (77 and $76 \mathrm{Tg} \mathrm{yr}^{-1}$ in Europe; 101 and $99 \mathrm{Tg} \mathrm{yr}^{-1}$ in North America) and IMPACT/IMPACT $1 \times 1$ (68 and $69 \mathrm{Tg} \mathrm{y}^{-1}$ in Europe; 97 and $100 \mathrm{Tg} \mathrm{yr}^{-1}$ in North America). The larger amplitude of the synoptic variability of TM5 $1 \times 1$ and IMPACT $1 \times 1$ does not result in larger fluxes, possibly because TM5 and IMPACT are already much more variable than LMDZ-SACS over these continents. On the contrary, differences between estimates of TM5/TM5 $1 \times 1$ and IMPACT/IMPACT $1 \times 1$ are relatively large in Africa (94 and $79 \mathrm{Tg} \mathrm{yr}^{-1}$ for TM5 versions and 81 and $72 \mathrm{Tg} \mathrm{yr}^{-1}$ for IMPACT versions) and in Oceania (29 and $38 \mathrm{Tg} \mathrm{yr}^{-1}$ for TM5 versions and 35 and $40 \mathrm{Tg} \mathrm{yr}^{-1}$ for IMPACT versions). Estimates in Asia and South America are characterized by large differences between TM5 and TM5 $1 \times 1$ (131 and $125 \mathrm{Tg} \mathrm{yr}^{-1}$ in Asia; 55 and $72 \mathrm{Tg} \mathrm{yr}^{-1}$ in South America), and small differences between IMPACT and IMPACT $1 \times 1\left(113\right.$ and $109 \mathrm{Tg} \mathrm{yr}^{-1}$ in Asia; 88 and $90 \mathrm{Tg} \mathrm{yr}^{-1}$ in South America). These larger changes could be the due to tropical regions being less constrained in the inversions.

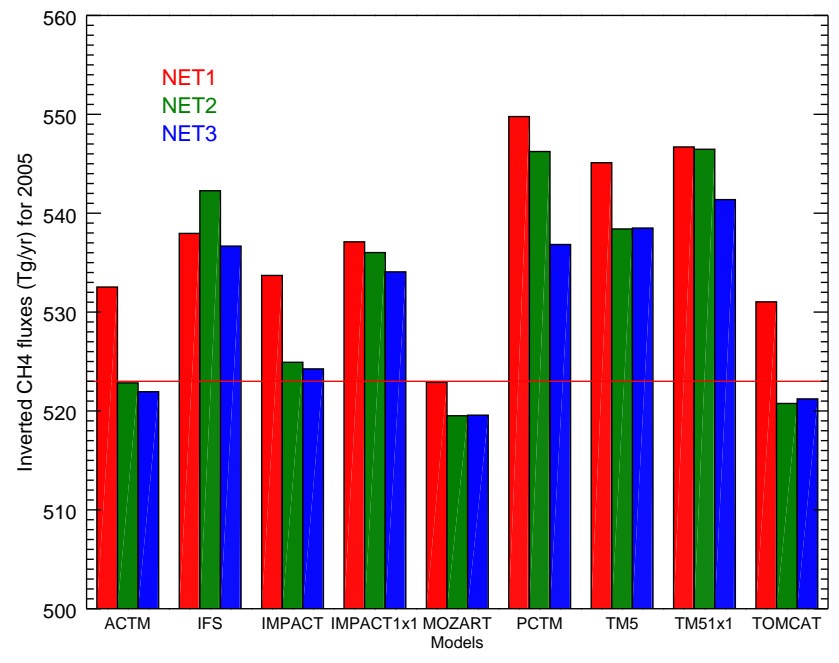

Fig. 14. Global methane estimates for every inversion using TransCom model outputs as synthetic observations in three network configurations. Results for NET1, NET2 and NET3 are respectively represented in red, green and blue. The red line shows the target value of the methane flux at the global scale $\left(523 \mathrm{Tg} \mathrm{yr}^{-1}\right)$.

\subsection{Sensitivity to the measurement network}

The fluxes inferred by atmospheric inversions are sensitive to the location and density of observations used to constrain them. We have used two other networks (NET2 and NET3) to assess the sensitivity of the modelling and transport errors on estimated fluxes to the network. NET2 assumes a mix of flasks and continuous data similar to the current situation. NET3 adds tower and aircraft measurements to NET2 (Sect. 2.4). 
Using NET2, the inverse system derives lower global estimates compared to emissions derived using the NET1 configuration for all synthetic datasets, except for IFS (Fig. 14). For instance, fluxes derived using ACTM, IMPACT and TM5 drop to 523,525 and $538 \mathrm{Tg} \mathrm{yr}^{-1}$ in 2005 , compared to 533 , 534 and $545 \mathrm{Tg} \mathrm{yr}^{-1}$ respectively in the case of NET1. If errors were unbiased and properly accounted in inversion, more constraints should ideally bring the estimated fluxes closer to the target. In other words, one could expect NET1 results to be closer to the target than NET2 fluxes. This discrepancy is discussed in more details in Sect. 4.

Estimates in the NET2 and NET3 configuration are very similar at the global scale, except for PCTM, IFS and the two high resolution versions of TM5 and IMPACT. Generally, the number of tall towers and aeroplane measurements is too low compared to the number of surface stations to produce a significant difference between estimates from NET2 and NET3 at the global scale. The higher horizontal resolution of IFS, IMPACT $1 \times 1$ and TM5 $1 \times 1$ is a possible explanation for the differences obtained in the global estimates between the NET2 and NET3 configuration. Moreover, PCTM tends to simulate very strong vertical gradients compared to other models (Saito et al., 2013), potentially due to the larger number of vertical layers in the PBL, which could explain the differences found between NET2 and NET3 emission estimates for PCTM. The impact of vertical resolution on the inversion could not be investigated further since two variants of a model with different vertical resolutions were not available.

At a regional scale, the additional information provided by tall towers and aeroplanes included in the inversions (NET3) effectively reduced the spread in flux estimates in the regions where these additional data are available compared to the NET2 inversions (Fig. 15). The spread decreases from 27 to $16 \mathrm{Tg} \mathrm{yr}^{-1}$ and from 7 to $4 \mathrm{Tg} \mathrm{yr}^{-1}$ for respectively North America and Boreal Eurasia. The estimates also move closer to the target emissions. Consequently, one can assume that the system cannot match all surface, tower and aircraft measurements and derives emissions closer to the target for these regions. In Europe, the spread does not change much between NET2 $\left(20 \mathrm{Tg} \mathrm{yr}^{-1}\right)$ and NET3 $\left(21 \mathrm{Tg} \mathrm{yr}^{-1}\right)$. Indeed, in our synthetic experiment, NET3 has only $20 \%$ additional synthetic observations in Europe compared to NET2. It suggests that NET3 estimates cannot be improved much in Europe compared to NET2 estimates. In regions where there are no additional synthetic observations in NET3 (South America, Africa and Oceania), inversions using NET3 synthetic observations are very similar to those obtained for NET2.

\section{Discussion}

The previous section shows that forcing and model errors have a significant impact on $\mathrm{CH}_{4}$ fluxes estimated by inverse modelling at the global scale. This impact is proportionally higher at regional and grid-cell scales. Several results highlighted in our study question the way that errors are specified in atmospheric inversions, with non-adapted errors in the $\mathbf{R}$ observation covariance matrix. For instance, a badly simulated IH exchange time can lead to biased interpretations of atmospheric signals, in terms of inverted fluxes, if the errors do not fully account for this modelling imperfection. In Sect. 3.4, it is shown that NET1 estimates of the global $\mathrm{CH}_{4}$ flux are further from the targeted flux as compared to NET2, even though more atmospheric constraints are considered in NET1 than in the NET2 configuration. Adding more constraints, as done in NET1, better defines in time and space the regional gradients of concentration between stations, which emphasizes, in terms of cost to be reduced in $J$, the differences between LMDZ-SACS and the other models. Associated with a potentially erroneous estimation of errors in the $\mathbf{R}$ matrix, especially concerning transport model errors, an amplification of the impact of errors can occur, leading to a larger difference in the global emissions compared to the target emissions, for NET1 compared to NET2. This effect is amplified by the fact that most stations moving from continuous to discontinuous (flask) when moving from NET1 to NET2 are remote stations with smaller model differences than continental continuous stations remaining in NET2. We have shown that discrepancies in synoptic variability at surface stations may result in different methane estimated fluxes in the area impacting these surface stations after transport. As highlighted in the Sect. 3.2.2, the PCTM estimate in North America is much higher than the other estimates. It is probably due to the fact that large uncertainties associated with the modelling of synoptic variability with LMDZ-SACS are not fully accounted for in the inversion. These elements suggest a misspecification of errors in the $\mathbf{R}$ matrix.

Table 4 compares the errors at 25 stations, representative of the different types of site encountered (background, polluted, coastal, continental, etc.) contained in the $\mathbf{R}$ matrix of Chen and Prinn (2006), Bergamaschi et al. (2005) and our study based on Globalview-CH4 (2009). The same order of magnitude for the errors is used in these studies, even if some large differences may be found at some specific stations. For instance, at Hegyátsál (Hungary) station, Chen and Prinn (2006) derive an error of $101.2 \mathrm{ppb}$ while the error given by Bergamaschi et al. (2005) is $26.5 \mathrm{ppb}$. The errors in our study generally lay between the errors used in these two studies. This means that observational errors used in this study are overall comparable to those currently used in other inversions. However, transport model errors in current inversions are generally not represented explicitly. Indeed, stateof-the-art inversions usually implement parameterizations of model errors, which quantify the misrepresentations of a surface station inside a larger grid box of the chemistry transport model. Chen and Prinn (2006) introduced a "mismatch" error term in the inversion process, aiming to mimic the representation error. This term is computed at each measurement site as the standard deviation of the $\mathrm{CH}_{4}$ mole fraction 
Table 4. Errors (in ppb) contained in $\mathbf{R}$ matrix of Chen and Prinn (2006), Bergamaschi et al. (2005) and our study at 25 surface stations.

\begin{tabular}{|c|c|c|c|c|}
\hline ID & station name & Chen and Prinn (2006) & Bergamaschi et al. (2005) & Our study \\
\hline ALT & Alert, Nunavut, Canada & 6.5 & 5.4 & 6.0 \\
\hline ZEP & Ny-Alesund, Svalbard, Spitsbergen & 13.3 & 6.8 & 9.3 \\
\hline BRW & Barrow, Alaska, USA & 21.9 & 12.2 & 13.7 \\
\hline BAL & Baltic Sea, Poland & 30.1 & 14.8 & 27.0 \\
\hline CBA & Cold Bay, Alaska, USA & 8.7 & 10.8 & 10.7 \\
\hline MHD & Mace Head, Ireland & 15.4 & 21.0 & 11.9 \\
\hline HUN & Hegyatsal, Hungary & 101.2 & 26.5 & 41.0 \\
\hline LEF & Park Falls, Wisconsin, USA & 21.9 & 13.0 & 22.8 \\
\hline BSC & Black Sea, Constanta, Romania & 46.4 & 41.9 & 43.1 \\
\hline $\mathrm{KZM}$ & Plateau Assy, Kazakhstan & 22.4 & 15.3 & 19.3 \\
\hline NWR & Niwot Ridge, Colorado, USA & 16.3 & 8.3 & 19.2 \\
\hline UTA & Wendover, Utah, USA & 27.7 & 13.2 & 20.7 \\
\hline TAP & Tae-ahn Peninsula, Republic of Korea & 54.9 & 33.1 & 40.3 \\
\hline WLG & Mt. Waliguan, Peoples Republic of China & 22.5 & 17.5 & 15.2 \\
\hline BME & St. Davis Head, Bermuda & 17.5 & 11.5 & 18.9 \\
\hline WIS & Sede Boker, Negev Desert, Israel & 17.8 & 13.6 & 23.9 \\
\hline ASK & Assekrem, Algeria & 11.2 & 5.7 & 7.7 \\
\hline MLO & Mauna Loa, Hawai, USA & 6.5 & 9.3 & 10.8 \\
\hline KUM & Cape Kumukahi, Hawai, USA & 10.6 & 8.5 & 10.0 \\
\hline RPB & Ragged Point, Barbados & 5.5 & 8.9 & 10.7 \\
\hline ASC & Ascension Island & 5.8 & 6.4 & 5.1 \\
\hline SMO & Cape Matatula, Tutuila, American Samoa & 4.9 & 7.6 & 7.9 \\
\hline CGO & Cape Grim, Tasmania, Australia & 5.2 & 8.9 & 5.8 \\
\hline \multirow[t]{2}{*}{ SPO } & South Pole, Antarctica & 7.6 & 3.0 & 1.6 \\
\hline & Average over all stations & 20.9 & 13.5 & 15.9 \\
\hline
\end{tabular}

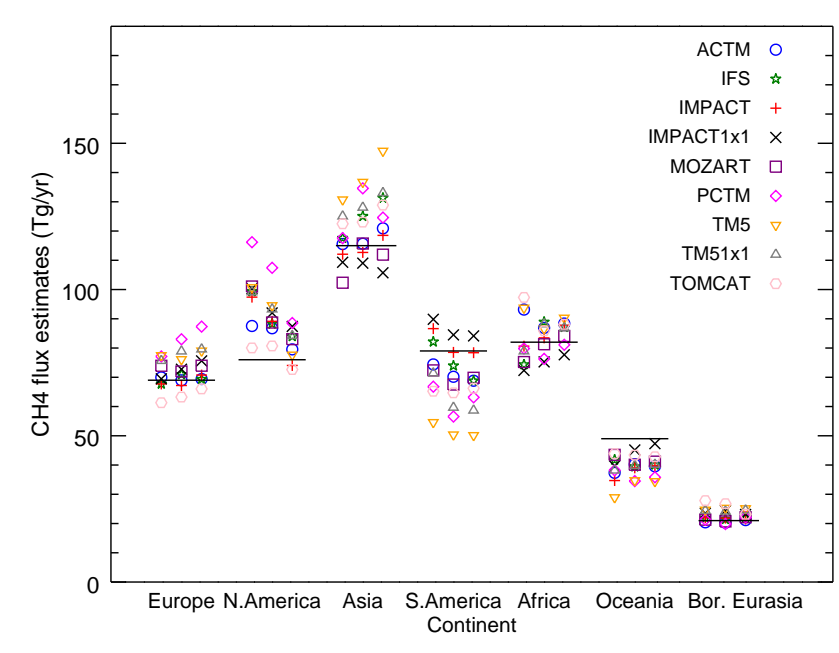

Fig. 15. Regional methane estimates for every inversion using TransCom model outputs as synthetic observations in three network configurations. Estimates for seven continental regions (Europe, North America, Asia, South America, Africa, Oceania and Boreal Eurasia) are shown. For every continental region, the first (second and third) column represents the estimates in the NET1 (NET2 and NET3, respectively) configuration. surrounding the observation site. Bergamaschi et al. (2005), similar to an approach described by Rödenbeck et al. (2003), took into consideration a "mismatch" (or "representativity") term that is related to spatial and temporal gradients in all the directions. Some other studies approximate transport errors by the variance of observations to take into account the fact that it is difficult for global transport models to properly represent large variations in trace gas concentrations (Bousquet et al., 2006; Geels et al., 2007). Bergamaschi et al. (2010) introduced a term assessing the uncertainty arising from the sub-grid scale variability of the emissions. These approaches, as with the one used in our study, only partly address the question of model and/or forcing errors, confirming that observation errors in methane inversions may be misspecified.

Moreover, in most state-of-the art inversions, only diagonal terms of $\mathbf{R}$ are specified when surface observations are assimilated. Nevertheless, both temporal and spatial correlations could also improve the specifications of errors and limit the impact of transport errors on the inverted estimates. For instance, we mentioned in Sect. 3.2.2 that the spread of fluxes in Western Europe may be higher in boreal winter due to more frequent and/or intense storms, suggesting a spatial correlation of transport model errors in Western Europe with errors in regions crossed by the storm tracks (the North Atlantic, for example). One could take into consideration 
the erroneous representation of the IH transport by including spatial correlations between stations from the Southern Hemisphere (or/and from the Northern Hemisphere). Figure 3 also points out that transport model errors may vary significantly from one season to another depending on seasonal emissions, suggesting that temporal correlations in measurement errors should be included in the measurement uncertainty covariance matrix. However, properly taking correlations into account dramatically slows down the inversion process. Chevallier (2007) proposed, for $\mathrm{CO}_{2}$ inversions, to inflate variances in order to limit the impact of unaccounted-for correlations on the accuracy of flux estimates as a computationally efficient method for indirectly considering correlations in future methane inversions.

Finally, our study faces some limitations. Firstly, one could question the development of an inverse modelling experiment assimilating synthetic observations in only one inversion model. However, at present, it is difficult to lead an inter-comparison of inverted fluxes with up-to-date methodologies (variational, ensemble methods, etc.) with the many models available in the TransCom- $\mathrm{CH}_{4}$ experiment, because it would require an inversion framework for each CTM with either an adjoint model (variational) or a large number of inversions (ensemble methods). It could also be debated that by using synthetic observations, the true transport model errors are not properly represented. Indeed, gaps between $\mathrm{CH}_{4}$ mixing ratios simulated by different CTMs may be different from gaps between observed and simulated $\mathrm{CH}_{4}$ mixing ratios (Stephens et al., 2007). Here, it is assumed that transport model errors are properly mapped by the large number of CTMs used in this experiment. Finally, the modelling of the different physical processes (advection, convection, turbulent mixing, etc.) and characteristics of the models (resolutions, vertical coordinate systems, meteorological fields) contributing to transport model errors are considered all together and cannot be explicitly separated, although there are insights that IH transport differences play an important role here. Additional knowledge given by different sensitivity tests, together with literature on the skill of each CTM in representing these different atmospheric processes, would likely provide enough information to separate the specific contributions to overall transport model errors of forcing errors and model errors.

\section{Conclusions}

A modelling exercise, based on a variational inversion, is presented to quantify the impact of transport model errors on methane emission estimates derived by inverse modelling.

Synthetic observations are created from 10 CTMs that participated in the TransCom- $\mathrm{CH}_{4}$ experiment and are used to constrain one atmospheric inversion framework with a common set-up. Therefore, inversions are only distinguished by the different simulated atmospheric transport, generating dif- ferent synthetic observational datasets. The spread between the inverted emission estimates shows that transport forcing and model errors have a significant impact on $\mathrm{CH}_{4}$ flux estimates. The range in global fluxes derived in the inversions is $5 \%\left(27 \mathrm{Tg} \mathrm{yr}^{-1}\right)$. Ranges of 23 to $48 \%$ are obtained in the fluxes derived at regional scales, and up to $150 \%$ at the model grid-scale. Over the continents, patterns of emissions can be very different, depending on the region and on the model used to generate synthetic observations. Consequently, our results show that transport model errors impact significantly the inverted methane budget at all scales, with an increasing impact when going from global to smaller scales.

The need to improve chemical transport models in order to improve inverse flux estimates by inverse modelling has been highlighted recently (Chevallier et al., 2010; Houweling et al., 2010; Saito et al., 2013). For instance, Saito et al. (2013) give some indications for the future development of more accurate CTMs by improving the modelling of inter-hemispheric transport in particular. Indeed, they show that the models with larger vertical gradients, coupled with slower horizontal transport, exhibit greater $\mathrm{CH}_{4}$ interhemispheric gradients in the lower troposphere. In LMDZSACS, which has relatively low inter-hemispheric exchange time (Patra et al., 2011), ongoing efforts are being made to improve the representation of vertical gradients by increasing the vertical resolution and by improving the modelling of physical processes in the planetary boundary layer.

The misrepresentation of transport model errors in methane inversions can exacerbate these modelling issues. Consequently, improved formulations of the observation covariance matrix $\mathbf{R}$, taking more into account more fully the transport model errors in order to mitigate their impacts on the estimated methane fluxes, have to be addressed in future inversions.

Acknowledgements. This work is supported by DGA (Direction Générale de l'Armement) and by CEA (Centre à l'Energie Atomique et aux Energies Alternatives). The research leading to the IFS results has received funding from the European Community's Seventh Framework Programme (FP7 THEME [SPA.2011.1.5-02]) under grant agreement n. 283576 in the context of the MACC-II project (Monitoring Atmospheric Composition and Climate -Interim Implementation). The contribution by the LLNL authors was prepared under Contract DE-AC52-07NA27344, with different parts supported by the IMPACTS project funded by the US DOE (BER) and project (07-ERD-064) funded by the LDRD program at LLNL. The TRANSCOM community is to be thanked for sustained efforts on transport model studies since 1993. We thank two anonymous reviewers for critical evaluation and providing very helpful comments and suggestions for improving this article.

Edited by: C. Gerbig 


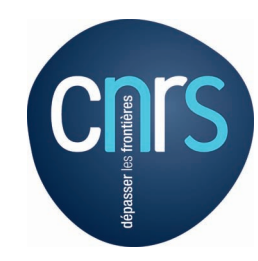

The publication of this article is financed by CNRS-INSU.

\section{References}

Allan, W., Struthers, H., and Lowe, D. C.: Methane carbon isotope effects caused by atomic chlorine in the marine boundary layer: Global model results compared with Southern Hemisphere measurements, J. Geophys. Res., 112, D04306, doi:10.1029/2006JD007369,2007.

Andreae, M. O. and Merlet, P.: Emission of trace gases and aerosols from biomass burning, Global Biogeochem. Cy., 15, 955-966, doi:10.1029/2000GB001382, 2001.

Arakawa, A. and Schubert, W.: Interaction of a cumulus cloud ensemble with the large-scale environment, Part I, J. Atmos. Sci., 31, 674-701, doi:10:1175/15200469(1974)031<0674:IOACCE>2:0:CO;2, 1974.

Aydin, M., Verhulst, K. R., Saltzman, E. S., Battle, M. O., Montzka, S. A., Blake, D. R., Tang, Q., and Prather, M. J.: Recent decreases in fossil-fuel emissions of ethane and methane derived from firn air, Nature, 476, 198-201, doi:10.1038/nature10352, 2011.

Baker, D. F., Law, R. M., Gurney, K. R., Rayner, P., Peylin, P., Denning, A. S., Bousquet, P., Bruhwiler, L., Chen, Y.-H., Ciais, P., Fung, I. Y., Heimann, M., John, J., Maki, T., Maksyutov, S., Masarie, K., Prather, M., Pak, B., Taguchi, S., and Zhu, Z.: TransCom 3 inversion intercomparison: Impact of transport model errors on the interannual variability of regional $\mathrm{CO}_{2}$ fluxes, 1988-2003, Global Biogeochem. Cy., 20, GB1002, doi:10.1029/2004GB002439, 2006.

Bechtold, P., Jung, T., Doblas-Reyes, F., Leutbecher, M., Rodwell, M. J., Vitart, F., and Balsamo, G.: Advances in simulating atmospheric variability with the ECMWF model: From synoptic to decadal time-scales, Q. J. Roy. Meteorol. Soc., 1337-1351, doi:10:1002/qj:289, 2008.

Belikov, D., Maksyutov, S., Miyasaka, T., Saeki, T., Zhuravlev, R., and Kiryushov, B.: Mass-conserving tracer transport modelling on a reduced latitude-longitude grid with NIES-TM, Geosci. Model Dev., 4, 207-222, doi:10.5194/gmd-4-207-2011, 2011.

Belikov, D. A., Maksyutov, S., Krol, M., Fraser, A., Rigby, M., Bian, H., Agusti-Panareda, A., Bergmann, D., Bousquet, P., Cameron-Smith, P., Chipperfield, M. P., Fortems-Cheiney, A., Gloor, E., Haynes, K., Hess, P., Houweling, S., Kawa, S. R., Law, R. M., Loh, Z., Meng, L., Palmer, P. I., Patra, P. K., Prinn, R. G., Saito, R., and Wilson, C.: Off-line algorithm for calculation of vertical tracer transport in the troposphere due to deep convection, Atmos. Chem. Phys., 13, 1093-1114, doi:10.5194/acp-131093-2013, 2013.

Bergamaschi, P., Krol, M., Dentener, F., Vermeulen, A., Meinhardt, F., Graul, R., Ramonet, M., Peters, W., and Dlugokencky, E. J.: Inverse modelling of national and European $\mathrm{CH}_{4}$ emissions using the atmospheric zoom model TM5, Atmos. Chem. Phys., 5, 2431-2460, doi:10.5194/acp-5-2431-2005, 2005.

Bergamaschi, P., Krol, M., Meirink, J. F., Dentener, F., Segers, A., van Aardenne, J., Monni, S., Vermeulen, A. T., Schmidt, M., Ramonet, M., Yver, C., Meinhardt, F., Nisbet, E. G., Fisher,
R. E., O'Doherty, S., and Dlugokencky, E. J.: Inverse modeling of European $\mathrm{CH}_{4}$ emissions 2001-2006, J. Geophys. Res., 115, D22309, doi:10.1029/2010JD014180, 2010.

Bian, H., Kawa, S. R., Chin, M., Pawson, S., Zhu, Z., Rasch, P., and $\mathrm{Wu}, \mathrm{S}$.: A test of sensitivity to convective transport in a global atmospheric $\mathrm{CO}_{2}$ simulation, Tellus B, 58, 463-475, doi:10.1111/j.1600-0889.2006.00212.x, 2006.

Bousquet, P., Ciais, P., Miller, J. B., Dlugokencky, E. J., Hauglustaine, D. A., Prigent, C., Van der Werf, G. R., Peylin, P., Brunke, E.-G., Carouge, C., Langenfelds, R. L., Lathière, J., Papa, F., Ramonet, M., Schmidt, M., Steele, L. P., Tyler, S. C., and White, J.: Contribution of anthropogenic and natural sources to atmospheric methane variability., Nature, 443, 439-443, doi:10.1038/nature05132, 2006.

Bousquet, P., Ringeval, B., Pison, I., Dlugokencky, E. J., Brunke, E.G., Carouge, C., Chevallier, F., Fortems-Cheiney, A., Frankenberg, C., Hauglustaine, D. A., Krummel, P. B., Langenfelds, R. L., Ramonet, M., Schmidt, M., Steele, L. P., Szopa, S., Yver, C., Viovy, N., and Ciais, P.: Source attribution of the changes in atmospheric methane for 2006-2008, Atmos. Chem. Phys., 11, 3689-3700, doi:10.5194/acp-11-3689-2011, 2011.

Chen, Y.-H. and Prinn, R. G.: Estimation of atmospheric methane emissions between 1996 and 2001 using a three-dimensional global chemical transport model, J. Geophys. Res., 111, 1-25, doi:10.1029/2005JD006058, 2006.

Chevallier, F., Fisher, M., Peylin, P., Serrar, S., Bousquet, P., Bréon, F.-M., Chédin, A., and Ciais, P.: Inferring $\mathrm{CO}_{2}$ sources and sinks from satellite observations: Method and application to TOVS data, J. Geophys. Res., 110, 1-13, doi:10.1029/2005JD006390, 2005.

Chevallier, F.: Impact of correlated observation errors on inverted $\mathrm{CO}_{2}$ surface fluxes from OCO measurements, Geophys. Res. Lett., 34, L24804, doi:10.1029/2007GL030463, 2007.

Chevallier, F., Feng, L., Bösch, H., Palmer, P. I., and Rayner, P. J.: On the impact of transport model errors for the estimation of $\mathrm{CO}_{2}$ surface fluxes from GOSAT observations, Geophys. Res. Lett., 37, L21803, doi:10.1029/2010GL044652, 2010.

Chipperfield, M. P.: New version of the TOMCAT/SLIMCAT offline chemical transport model: Intercomparison of stratospheric tracer experiments, Q. J. Roy. Meteorol. Soc., 132, 1179-1203, doi:10.1256/qj.05.51, 2006.

Corbin, K. D. and Law, R. M.: Extending atmospheric CO2 and tracer capabilities in ACCESS, CAWCR Technical Report No. 035, The Centre for Australian Weather and Climate Research, ISBN: 978-1-921826-177, Aspendale, 2011.

Denman, K. L., Marquis, M., Averyt, K. B., and Kingdom, U.: Couplings Between Changes in the Climate System and Biogeochemistry, The Physical Basis of Climate Change, Contribution of Working Group I to the Fourth Assessment Report of the IPCC, edited by: Solomon, S., Qin, D., Manning, M., Chen, Z., Marquis, M., Averyt, K. B., Tignor, M., and Miller, H. L., Cambridge University Press, Cambridge, UK and New York, NY, 500-587, USA.

Denning, A. S., Holzer, M., Gurney, K. R., Heimann, M., Law, R. M., Rayner, P. J., Fung, I. Y., Fan, S.-M., Taguchi, S., Friedlingstein, P., Balkanski, Y., Taylor, J., Maiss, M., and Levin, I.: Three-dimensional transport and concentration of $\mathrm{SF}_{6}, \mathrm{~A}$ model intercomparison study (TransCom 2), Tellus B, 51, 266297, doi:10.1034/j.1600-0889.1999.00012.x, 1999. 
Dlugokencky, E. J., Nisbet, E. G., Fisher, R., and Lowry, D.: Global atmospheric methane: budget, changes and dangers, Philos. T. Roy. Soc. A, 369, 2058-2072, doi:10.1098/rsta.2010.0341, 2011. EDGAR-v4.2 - Emission Database for Global Atmospheric Research (EDGAR), JRC/PBL (Joint Research Center of the European Commission/Netherlands Environmental Assessment Agency): release version 4.2, http://edgar.jrc.ec.europa.eu (last access: September 2013), 2011.

Emmons, L. K., Walters, S., Hess, P. G., Lamarque, J.-F., Pfister, G. G., Fillmore, D., Granier, C., Guenther, A., Kinnison, D., Laepple, T., Orlando, J., Tie, X., Tyndall, G., Wiedinmyer, C., Baughcum, S. L., and Kloster, S.: Description and evaluation of the Model for Ozone and Related chemical Tracers, version 4 (MOZART-4), Geosci. Model Dev., 3, 43-67, doi:10.5194/gmd3-43-2010, 2010.

Engelen, R. J., Denning, A. S., and Gurney, K. R.: On error estimation in atmospheric $\mathrm{CO}_{2}$ inversions, J. Geophys. Res., 107, 4635, doi:10.1029/2002JD002195, 2002.

Errico, R.: What is an adjoint model?, B. Am. Meteorol. Soc., 78, 2577-2591, 1997.

Etheridge, D., Pearman, G., and Fraser, P.: Changes in tropospheric methane between 1841 and 1978 from a high accumulation rate Antarctic ice core, Tellus B, 44, 282-294, doi:10.1034/j.16000889.1992.t01-3-00006.x, 1992.

Fiore, A. M., Jacob, D. J., Field, B. D., Streets, D. G., Fernandes, S. D., and Jang, C.: Linking ozone pollution and climate change: The case for controlling methane, Geophys. Res. Lett., 78, 25772591, doi:10.1029/2002GL015601, 2002.

Fraser, A., Miller, C. C., Palmer, P. I., Deutscher, N. M., Jones, N. B., and Griffith, D. W. T.: The Australian methane budget: Interpreting surface and train-borne measurements using a chemistry transport model, J. Geophys. Res., 116, D20306, doi:10.1029/2011JD015964, 2011.

Geels, C., Gloor, M., Ciais, P., Bousquet, P., Peylin, P., Vermeulen, A. T., Dargaville, R., Aalto, T., Brandt, J., Christensen, J. H., Frohn, L. M., Haszpra, L., Karstens, U., Rödenbeck, C., Ramonet, M., Carboni, G., and Santaguida, R.: Comparing atmospheric transport models for future regional inversions over Europe - Part 1: mapping the atmospheric $\mathrm{CO}_{2}$ signals, Atmos. Chem. Phys., 7, 3461-3479, doi:10.5194/acp-7-3461-2007, 2007.

Gent, P., Yeager, S., Neale, R., Levis, S., and Bailey, D.: Improvements in a half degree atmosphere/land version of the CCSM, Clim. Dynam., 34, 819-833, doi:10.1007/s00382-009-0614-8, 2010.

Gerbig, C., Körner, S., and Lin, J. C.: Vertical mixing in atmospheric tracer transport models: error characterization and propagation, Atmos. Chem. Phys., 8, 591-602, doi:10.5194/acp-8591-2008, 2008.

GLOBALVIEW-CH4: Cooperative Atmospheric Data Integration Project - Methane, also available on Internet via anonymous FTP to ftp.cmdl.noaa.gov, Path: ccg/ch4/GLOBALVIEW, CD-ROM, NOAA ESRL, Boulder, Colorado, 2009.

Gloor, M., Fan, S.-M., Pacala, S., Sarmiento, J., and Ramonet, M.: A model-based evaluation of inversions of atmospheric transport, using annual mean mixing ratios, as a tool to monitor fluxes of nonreactive trace substances like $\mathrm{CO}_{2}$ on a continental scale, J. Geophys. Res., 104, 14245, doi:10.1029/1999JD900132, 1999.
Gurney, K. R., Law, R. M., Denning, A. S., Rayner, P. J., Baker, D., Bousquet, P., Bruhwilerk, L., Chen, Y.-H., Ciais, P., Fan, S., and Fung, I. Y.: Towards robust regional estimates of $\mathrm{CO}_{2}$ sources and sinks using atmospheric transport models, Nature, 415, 626630, doi:10.1038/415626a, 2002.

Hein, R., Crutzen, P. J., and Heimann, M.: An inverse modeling approach to investigate the global atmospheric methane cycle, Global Biogeochemical Cycles, 11, 43, doi:10.1029/96GB03043, 1997.

Holtslag, A. A. M. and Boville, B. A.: Local versus nonlocal boundary-layer diffusion in a global climate model, J. Climate, 6, 1825-1842, doi:10.1175/15200442(1993)006<1825:LVNBLD>2.0.CO;2, 1993.

Holtslag, A. A. M. and Moeng, C.-H.: Eddy diffusivity and countergradient transport in the convective atmospheric boundary layer, Journal of Atmospheric Sciences, 48, 1690-1698, doi:10.1175/15200469(1991)048\%3C1690:EDACTI\%3E2.0.CO;2, 1991.

Hortal, M.: The development and testing of a new two-timelevel semi-Lagrangian scheme (SETTLS) in the ECMWF forecast model, Q. J. Roy. Meteorol. Soc., 2, 1671-1687, doi:10.1002/qj.200212858314,2002.

Hourdin, F. and Armengaud, A.: The use of finite-volume methods for atmospheric advection of trace species, Part I: Test of various formulations in a general circulation model, Mon. Weather Rev., 127, 822-837, doi:10.1175/15200493(1999)127\%3C0822:TUOFVM\%3E2.0.CO;2, 1999.

Hourdin, F., Musat, I., Bony, S., Braconnot, P., Codron, F., Dufresne, J.-L., Fairhead, L., Filiberti, M.-A., Friedlingstein, P., Grandpeix, J.-Y., Krinner, G., LeVan, P., Li, Z.-X., and Lott, F.: The LMDZ4 general circulation model: climate performance and sensitivity to parametrized physics with emphasis on tropical convection, Clim. Dynam., 27, 787-813, doi:10.1007/s00382006-0158-0, 2006.

Houweling, S., Kaminski, T., Dentener, F., Lelieveld, J., and Heimann, M.: Inverse modeling of methane sources and sinks using the adjoint of a global transport model, J. Geophys. Res., 104, 26137, doi:10.1029/1999JD900428, 1999.

Houweling, S., Aben, I., Breon, F.-M., Chevallier, F., Deutscher, N., Engelen, R., Gerbig, C., Griffith, D., Hungershoefer, K., Macatangay, R., Marshall, J., Notholt, J., Peters, W., and Serrar, S.: The importance of transport model uncertainties for the estimation of $\mathrm{CO}_{2}$ sources and sinks using satellite measurements, Atmos. Chem. Phys., 10, 9981-9992, doi:10.5194/acp-10-99812010, 2010.

Houweling, S., Badawy, B., and Baker, D.: Iconic $\mathrm{CO}_{2}$ time series at risk, Science, 337, 1038-1040, doi:10.1126/science.337.6098.1038-b, 2012.

Kai, F. M., Tyler, S. C., Randerson, J. T., and Blake, D. R.: Reduced methane growth rate explained by decreased Northern Hemisphere microbial sources, Nature, 476, 194-197, doi:10.1038/nature10259, 2011.

Kaminski, T., Rayner, P. J., Heimann, M., and Enting, I. G.: On aggregation errors in atmospheric transport inversions, J. Geophys. Res., 106, 4703, doi:10.1029/2000JD900581, 2001.

Kawa, S. R., Erickson III, D. J., Pawson, S., and Zhu, Z.: Global $\mathrm{CO}_{2}$ transport simulations using meteorological data from the NASA data assimilation system, J. Geophys. Res., 109, D18312, doi:10.1029/2004JD004554, 2004. 
Kirschke, S., Bousquet, P., Ciais, P., Saunois, M., Bergamaschi, P., Bergmann, D., Bruhwiler, L., Cameron-Smith, P., Canadell, J. G., Castaldi, S., Chevallier, F., Dlugokencky, E. J., Feng, L., Fraser, A., Heimann, M., Hodson, E. L., Houweling, S., Josse, B., Lamarque, J.-F., Le Quére, C., Naik, V., Palmer, P. I., Pison, I., Plummer, D., Poulter, B., Ringeval, B., Santini, M., Schmidt, M., Shindell, D. T., Spahni, R., Strode, S. A., Sudo, K., Szopa, S., van der Werf, G. R., Voulgarakis, A., wvan Weele, M., Williams, J. E., and Zeng, G.: Three decades of methane sources and sinks: budgets and variations, Nat. Geosci., 6, 813823, doi:10:1038/ngeo1955, 2013.

Köhler, M., Ahlgrimm, M., and Beljaars, A.: Unified treatment of dry convective and stratocumulus-topped boundary layers in the ECMWF model, Q. J. Roy. Meteorol. Soc., 137, 43-57, doi:10.1002/qj.713, 2011.

Krol, M., Houweling, S., Bregman, B., van den Broek, M., Segers, A., van Velthoven, P., Peters, W., Dentener, F., and Bergamaschi, P.: The two-way nested global chemistry-transport zoom model TM5: algorithm and applications, Atmos. Chem. Phys., 5, 417432, doi:10.5194/acp-5-417-2005, 2005.

Laval, K., Sadourny, R., and Serafini, Y.: Land surface processes in a simplified general circulation model, Geophys. Astrophys. Fluid Dyn., 17, 129-150, 1981.

Law, R., Rayner, P., Denning, A. S., Erickson, D., Fung, I. Y., Heimann, M., Piper, S. C., Ramonet, M., Taguchi, S., Taylor, J. A., Trudinger, C. M., and Watterson, I. G.: Variations in modeled atmospheric transport of carbon dioxide and the consequences for $\mathrm{CO}_{2}$ inversions, Global Biogeochem. Cy., 10, 783796, doi:10.1029/96GB01892, 1996.

Law, R. M., Rayner, P. J., Steele, L. P., and Enting, I. G.: Data and modelling requirements for $\mathrm{CO}_{2}$ inversions using highfrequency data, Tellus B, 55, 512-521, doi:10.1034/j.16000889.2003.00029.x, 2002.

Law, R. M., Kowalczyk, E. A., and Wang, Y.-P.: Using atmospheric $\mathrm{CO}_{2}$ data to assess a simplified carbon-climate simulation for the 20th century, Tellus B, 58, 427-437, doi:10.1111/j.16000889.2006.00198.x, 2006.

Leer, B. V.: Towards the ultimate conservative difference scheme, IV. A new approach to numerical convection, J. Comput. Phys., 23, 276-299, doi:10.1016/0021-9991(77)90095-X, 1977.

Levin, I., Veidt, C., Vaughn, B. H., Brailsford, G., Bromley, T., Heinz, R., Lowe, D., Miller, J. B., Poß, C., and White, J. W. C.: No inter-hemispheric $\delta^{13} \mathrm{CH}_{4}$ trend observed, Nature, 486, 3-4, doi:10.1038/nature11175, 2012.

Lin, J. C., and Gerbig, C.: Accounting for the effect of transport errors on tracer inversions, Geophys. Res. Lett., 32, L01802, doi:10.1029/2004GL021127, 2005.

Lin, S. and Rood, R.: Multidimensional flux-form semi-Lagrangian transport schemes, Mon. Weather Rev., 124, 2046-2070, doi:10.1175/1520-0493(1996)124<2046:MFFSLT>2.0.CO;2, 1996.

Lock, A., Brown, A., and Bush, M.: A new boundary layer mixing scheme, Part I: Scheme description and single-column model tests, Monthly weather review, 3187-3199, doi:10.1175/15200493(2000)128<3187:ANBLMS>2.0.CO;2, 2000.

Louis, J.: A parametric model of vertical eddy fluxes in the atmosphere, Bound.-Lay. Meteorol., 7, 187-202, doi:10.1007/BF00117978, 1979.
Meirink, J. F., Bergamaschi, P., and Krol, M. C.: Fourdimensional variational data assimilation for inverse modelling of atmospheric methane emissions: method and comparison with synthesis inversion, Atmos. Chem. Phys., 8, 6341-6353, doi:10.5194/acp-8-6341-2008, 2008.

Montzka, S. A., Dlugokencky, E. J., and Butler, J. H.: Non$\mathrm{CO}_{2}$ greenhouse gases and climate change, Nature, 476, 43-50, doi:10.1038/nature10322, 2011.

Patra, P. K., Takigawa, M., Ishijima, K., Choi, B.-C., Cunnold, D., Dlugokencky, E. J., Fraser, P., Gomez-Pelaez, A. J., Goo, T.-Y., Kim, J.-S., Krummel, P., Langenfelds, R., Meinhardt, F., Mukai, H., O’Doherty, S., Prinn, R. G., Simmonds, P., Steele, P., Tohjima, Y., Tsuboi, K., Uhse, K., Weiss, R., Worthy, D., and Nakazawa, T.: Growth Rate, Seasonal, Synoptic, Diurnal Variations and Budget of Methane in the Lower Atmosphere, J. Meteorol. Soc. Jpn., 87, 635-663, doi:10.2151/jmsj.87.635, 2009.

Patra, P. K., Houweling, S., Krol, M., Bousquet, P., Belikov, D., Bergmann, D., Bian, H., Cameron-Smith, P., Chipperfield, M. P., Corbin, K., Fortems-Cheiney, A., Fraser, A., Gloor, E., Hess, P., Ito, A., Kawa, S. R., Law, R. M., Loh, Z., Maksyutov, S., Meng, L., Palmer, P. I., Prinn, R. G., Rigby, M., Saito, R., and Wilson, C.: TransCom model simulations of $\mathrm{CH}_{4}$ and related species: linking transport, surface flux and chemical loss with $\mathrm{CH}_{4}$ variability in the troposphere and lower stratosphere, Atmos. Chem. Phys., 11, 12813-12837, doi:10.5194/acp-11-12813-2011, 2011.

Peylin, P., Rayner, P. J., Bousquet, P., Carouge, C., Hourdin, F., Heinrich, P., Ciais, P., and AEROCARB contributors: Daily $\mathrm{CO}_{2}$ flux estimates over Europe from continuous atmospheric measurements: 1, inverse methodology, Atmos. Chem. Phys., 5, 3173-3186, doi:10.5194/acp-5-3173-2005, 2005.

Pickett-Heaps, C. A., Jacob, D. J., Wecht, K. J., Kort, E. A., Wofsy, S. C., Diskin, G. S., Worthy, D. E. J., Kaplan, J. O., Bey, I., and Drevet, J.: Magnitude and seasonality of wetland methane emissions from the Hudson Bay Lowlands (Canada), Atmos. Chem. Phys., 11, 3773-3779, doi:10.5194/acp-11-3773-2011, 2011.

Pison, I., Bousquet, P., Chevallier, F., Szopa, S., and Hauglustaine, D.: Multi-species inversion of $\mathrm{CH}_{4}, \mathrm{CO}$ and $\mathrm{H}_{2}$ emissions from surface measurements, Atmos. Chem. Phys., 9, 5281-5297, doi:10.5194/acp-9-5281-2009, 2009.

Prather, M.: Numerical advection by conservation of secondorder moments, J. Geophys. Res., 91, 6671-6681, doi:10.1029/JD091iD06p06671, 1986.

Prinn, R. G., Weiss, R. F., Fraser, P. J., Simmonds, P. G., Cunnold, D. M., Alyea, F. N., O’Doherty, S., Salameh, P., Miller, B. R., Huang, J., Wang, R. H. J., Hartley, D. E., Harth, C., Steele, L. P., Sturrock, G., Midgley, P. M., and McCulloch, A.: A history of chemically and radiatively important gases in air deduced from ALE/GAGE/AGAGE, J. Geophys. Res., 105, 1775117792, doi:10.1029/2000JD900141, 2000.

Rasch, P. and Kristjánsson, J.: A comparison of the CCM3 model climate using diagnosed and predicted condensate parameterizations, J. Climate, 11, 1587-1614, doi:10.1175/15200442(1998)011<1587:ACOTCM>2.0.CO;2, 1998.

Rigby, M., Prinn, R. G., Fraser, P. J., Simmonds, P. G., Langenfelds, R. L., Huang, J., Cunnold, D. M., Steele, L. P., Krummel, P. B., Weiss, R. F., O’Doherty, S., Salameh, P. K., Wang, H. J., Harth, C. M., Mühle, J., and Porter, L. W.: Renewed growth of atmospheric methane, Geophys. Res. Lett., 35, L22805, doi:10.1029/2008GL036037, 2008. 
Rödenbeck, C., Houweling, S., Gloor, M., and Heimann, M.: $\mathrm{CO}_{2}$ flux history 1982-2001 inferred from atmospheric data using a global inversion of atmospheric transport, Atmos. Chem. Phys., 3, 1919-1964, doi:10.5194/acp-3-1919-2003, 2003.

Rotman, D. A.: IMPACT, the LLNL 3-D global atmospheric chemical transport model for the combined troposphere and stratosphere: Model description and analysis of ozone and other trace gases, J. Geophys. Res., 109, D04303, doi:10.1029/2002JD003155, 2004.

Russell, G. and Lerner, J.: A new finite-differencing scheme for the tracer transport equation, J. Appl. Meteorol., 20, 1483-1498, doi:10.1175/1520-0450(1981)020<1483:ANFDSF>2.0.CO;2, 1981.

Saito, R., Patra, P., Sweeney, C., Machida, T., Krol, M., Houweling, S., Bousquet, P., Agusti-panareda, A., Belikov, D., Bergmann, D., Bian, H., Cameron-Smith, P., Chipperfield, M., FortemsCheney, A., Fraser, A., Gatti, M., Gloor, E., Hess, P., Kawa, S., Law, R., Locatelli, R., Loe, Z., Maksyutov, S., Meng, L., Miller, J., Palmer, P., Prinn, R., Rigby, M., and Wilson, C.: TransCom model simulations of methane: comparison of vertical profiles with in situ aircraft measurements, J. Geophys. Res., 118, 38913904, 2013.

Simpson, I. J., Sulbaek Andersen, M. P., Meinardi, S., Bruhwiler, L., Blake, N. J., Helmig, D., Rowland, F. S., and Blake, D. R.: Long-term decline of global atmospheric ethane concentrations and implications for methane, Nature, 488, 490-494, doi:10.1038/nature11342, 2012.

Spahni, R., Chappellaz, J., Stocker, T. F., Loulergue, L., Hausammann, G., Kawamura, K., Flückiger, J., Schwander, J., Raynaud, D., Masson-Delmotte, V., and Jouzel, J.: Atmospheric methane and nitrous oxide of the Late Pleistocene from Antarctic ice cores, Science, 310, 1317-1321, doi:10.1126/science.1120132, 2005.

Spivakovsky, C. M., Logan, J. A., Montzka, S. A., Balkanski, Y. J., Foreman-Fowler, M., Jones, D. B. A., Horowitz, L. W., Fusco, A. C., Brenninkmeijer, C. A. M., Prather, M. J., Wofsy, S. C., and McElroy, M. B.: Three-dimensional climatological distribution of tropospheric OH: Update and evaluation, J. Geophys. Res., 105, 8931, doi:10.1029/1999JD901006, 2000.

Stephens, B. B., Gurney, K. R., Tans, P. P., Sweeney, C., Peters, W., Bruhwiler, L., Ciais, P., Ramonet, M., Bousquet, P., Nakazawa, T., Aoki, S., Machida, T., Inoue, G., Vinnichenko, N., Lloyd, J., Jordan, A., Heimann, M., Shibistova, O., Langenfelds, R. L., Steele, L. P., Francey, R. J., and Denning, A. S.: Weak northern and strong tropical land carbon uptake from vertical profiles of atmospheric $\mathrm{CO}_{2}$, Science, 316, 1732-1735, doi:10.1126/science.1137004, 2007.
Taguchi, S., Law, R. M., Rödenbeck, C., Patra, P. K., Maksyutov, S., Zahorowski, W., Sartorius, H., and Levin, I.: TransCom continuous experiment: comparison of ${ }^{222} \mathrm{Rn}$ transport at hourly time scales at three stations in Germany, Atmos. Chem. Phys., 11, 10071-10084, doi:10.5194/acp-11-10071-2011, 2011.

Tarantola, A.: Inverse Problem Theory, Society for Industrial and Applied Mathematics, Philiadelphia, USA, 2005.

Tiedtke, M.: A comprehensive mass flux scheme for cumulus parameterization in large-scale models, Mon. Weather Rev., 117, 1779-1800, doi:10.1175/15200493(1989)117<1779:ACMFSF>2.0.CO;2, 1989.

van der Werf, G. R., Randerson, J. T., Giglio, L., Collatz, G. J., Mu, M., Kasibhatla, P. S., Morton, D. C., DeFries, R. S., Jin, Y., and van Leeuwen, T. T.: Global fire emissions and the contribution of deforestation, savanna, forest, agricultural, and peat fires (19972009), Atmos. Chem. Phys., 10, 11707-11735, doi:10.5194/acp10-11707-2010, 2010.

Walton, J., MacCracken, M., and Ghan, S.: A global-scale Lagrangian trace species model of transport, transformation, and removal processes, J. Geophys. Res., 93, 8339-8354, doi:10.1029/JD093iD07p08339, 1988.

Yver, C. E., Pison, I. C., Fortems-Cheiney, A., Schmidt, M., Chevallier, F., Ramonet, M., Jordan, A., Søvde, O. A., Engel, A., Fisher, R. E., Lowry, D., Nisbet, E. G., Levin, I., Hammer, S., Necki, J., Bartyzel, J., Reimann, S., Vollmer, M. K., Steinbacher, M., Aalto, T., Maione, M., Arduini, J., O’Doherty, S., Grant, A., Sturges, W. T., Forster, G. L., Lunder, C. R., Privalov, V., Paramonova, N., Werner, A., and Bousquet, P.: A new estimation of the recent tropospheric molecular hydrogen budget using atmospheric observations and variational inversion, Atmos. Chem. Phys., 11, 3375-3392, doi:10.5194/acp-11-3375-2011, 2011.

Zhang, G. and McFarlane, N.: Sensitivity of climate simulations to the parameterization of cumulus convection in the Canadian Climate Centre general circulation model, Atmos.-Ocean, 33, 407446, doi:10.1080/07055900.1995.9649539, 1995. 